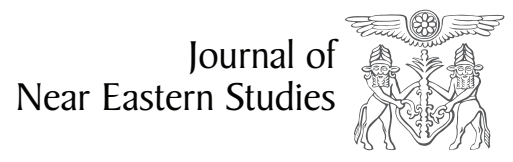

\title{
A New Look at Old Numbers, and What It Reveals about Numeration
}

\author{
KaRENLEIGH A. OvermanN, University of Bergen*
}

\begin{abstract}
A particular number is not identical with any collection of terms having that number: the number 3 is not identical with the trio consisting of Brown, Jones, and Robinson. The number 3 is something which all trios have in common, and which distinguishes them from other collections. Bertrand Russell, Introduction to Mathematical Philosophy (1920), 11-12.
\end{abstract}

\section{Introduction}

An inquiry into numbers should start with what numbers are, and here the opening quotation from the philosopher and mathematician Bertrand Russell is appropriate. He defined a number not as the quantity of a set of objects, but rather as quantity shared by sets of objects. From a cognitive standpoint, the apprehension of a shared property is abstraction, and the conceptual products or concepts that are formed are "abstract." Abstraction forms "abstract" concepts by identifying properties common to sets of objects, inducting from particulars, and applying inductive insights to new domains; extracting content from its original circumstances to remove their influence on its meaning; combining parts to form wholes, often in such a way that sums are greater than their constitutive parts; and reinterpreting processes or relations as permanent entities in their own right, making

\footnotetext{
* This project has received funding from the European Union's Horizon 2020 research and innovation program under grant agreement No. 785793. Andrea Bender, University of Bergen, offered helpful comments on the Tongan material, and two anonymous reviewers improved the manuscript with their critical comments. This article is dedicated to the memory of Robert K. Englund, whose interest in and encouragement of my research in Mesopotamian numeracy will be greatly missed.
}

them available to act as inputs to other processes or relations. ${ }^{1}$

As an ineffable concept of quantity shared between sets of objects, a number is easily visualized and expressed in material form, ${ }^{2}$ as for example by pointing to something that has the quantity in question or by displaying the requisite quantity of fingers. A material form like the fingers that represents by instantiating quantity then acts as a reference set for the set of enumerated objects. Visualizing numbers is not merely enabled by the use of material forms, it arguably depends on them, since language has little capacity to instantiate quantity. ${ }^{3}$ Material instantiation not only occasions

\footnotetext{
${ }^{1}$ Dreyfus, "Advanced Mathematical Thinking Processes" (1991); Ferrari, "Abstraction in Mathematics" (2003); Gray and Tall, "Duality, Ambiguity" (1994); Sfard and Linchevski, "Gains and Pitfalls" (1994).

${ }^{2}$ Malafouris, "Grasping the Concept" (2010), 40.

${ }^{3}$ Language has little instantiative capacity because syllabic quantity is not what makes number-words numerically meaningful. An exception is found in Brazil, where Mundurucu lexical numbers instantiate quantity through the number of syllables (Rooryck, et al., "Mundurucu Number Words" [2017]). These also denote objects whose quantity exemplifies the number in question, the indexical use of language more typical in emerging numbers. Mundurucu numbers count to about four, a range consistent with the biological endowment for appreciating quantity. The perceptible range of small
} 
naming in language, it influences numerical properties, as for example, using the fingers influences numbers toward organization by tens. Instantiation also yields a contiguity between forms like fingers, tallies, tokens, and notations that has no counterpart in non-numerical language. ${ }^{4}$

When does a concept of shared quantity, an "abstract" concept of number, emerge from the perceptual experience of quantity? The so-called number sense enables us to appreciate quantities up to about three or four ("subitization") and above that amount, appreciate the difference between larger and smaller quantities ("magnitude appreciation"), assuming the difference is above a threshold of noticeability. ${ }^{5}$ This perceptual system influences the way numbers emerge across languages and cultures as one, two, (perhaps) about three or four, and many, as typically expressed through gestural or linguistic reference to objects with the requisite quantity. Arguably, as soon as such reference sets become involved, a connection between sets is indicated. However, emergent numbers differ from the modern Western construct often assumed to typify what numbers are as concepts, ${ }^{6}$ acquiring properties of content, structure, and organization as they become elaborated.

As a concept, a number is thus abstract from its inception; it is also concrete in depending on material forms, both the physical objects that have quantity and the reference sets that share and represent quantity and signal connections between sets. ${ }^{7}$ This dependence on material form remains true even for highly elaborated numbers mediated by notations, like those of the Western numerical tradition, ${ }^{8}$ as notations have a material aspect that is often overlooked in emphasizing their symbolic qualities. ${ }^{9}$ In short, numbers do not start out "concrete" to become "abstract" at some later point in time, a historical notion and associated labels that are problematic, as will be discussed. However, the way in which numbers are conceptualized

quantities, which is limited to about three or four, effectively precludes the use of syllabic instantiation to represent higher numbers.

${ }^{4}$ Malafouris, How Things Shape the Mind (2013), 89-118 differentiates the linguistic from the material sign; Overmann applies this distinction to numbers in Material Origin (2019), 19-24.

5 Piazza, "Neurocognitive Start-up Tools" (2010): 542; also see Dehaene, "Neural Basis" (2003).

${ }^{6}$ Rotman, Mathematics as Sign (2000), 40.

${ }^{7}$ Overmann, Material Origin (2019), 53-56, 219-21.

${ }^{8}$ Schlimm, "Numbers through Numerals" (2018).

9 Overmann, "Constructing a Concept" (2018): 465. does change, since they do not emerge in the form of the Western numbers familiar to most researchers. This conceptual change is the phenomenon we want to understand, in terms of both the process and mechanisms that cause change over time and the resultant differences in elaboration.

As numbers are abstract from their inception and remain materially bound even at their most elaborated, new terms and concepts are needed to understand the phenomenon of conceptual change. This is particularly true in Near Eastern studies, where for decades, the labels "abstract" and "concrete" have dominated how the archaic number systems of Mesopotamia have been understood, chiefly through the work of archaeologist Denise Schmandt-Besserat ${ }^{10}$ and psychologist Peter Damerow. ${ }^{11}$ In the decades since these works were produced, research in numerical cognition has grown considerably, yielding new insights into cognitive, linguistic, and ethnographic aspects of numbers and numeracy. And in the past ten years, new paradigms in cognitive archaeology have been used to examine the role of material forms in numerical cognition, particularly in realizing and elaborating numerical concepts. ${ }^{12}$

Schmandt-Besserat drew upon work by sociologist Lucian Lévy-Bruhl, ${ }^{13}$ whose cultural psychology categorized societies as "primitive" or "civilized." Perhaps because it was consistent with Lévy-Bruhl's view of societal modes of thinking as progressively evolving, Schmandt-Besserat appropriated a quote from Bertrand Russell:

It is only at a high stage of civilisation that we could take [the series of natural numbers] as our starting-point. It must have required many ages to discover that a brace of pheasants and a couple

${ }^{10}$ E.g., Schmandt-Besserat, "Use of Clay" (1974), "Archaic Recording System" (1977), "Earliest Precursor" (1978), "From Tokens to Tablets" (1981), "Emergence of Recording" (1982), How Writing Came About (1992), and Before Writing (1992).

${ }^{11}$ E.g., Damerow, Abstraction and Representation (2010), 27597; also see "Individual Development" (1988), "Number as a SecondOrder Concept" (1996), "Prehistory and Cognitive Development" (1996), "Material Culture" (2007), and "Origins of Writing and Arithmetic" (2012).

12 Malafouris, "Grasping the Concept" (2010) and How Things Shape the Mind (2013), 106-16; Overmann, "Beyond Writing" (2016) and "Role of Materiality" (2016).

${ }^{13}$ Schmandt-Besserat, "Emergence of Recording" (1982): 873, cited Lévy-Bruhl's publication, Les Fonctions Mentales dans les Sociétés Inférieures (1912). 
of days were both instances of the number 2: the degree of abstraction involved is far from easy. ${ }^{14}$

However, where Russell perhaps observed the intangibility of both numbers and time, Schmandt-Besserat used the quote to claim that Neolithic peoples were unable to recognize quantity shared between sets of physical (tangible) objects, including the small, geometrically shaped clay objects known as "tokens" used as numerical counters during the Neolithic. To SchmandtBesserat, tokens had no inherent numerical meaning or relation to one another beyond representing, in strict one-to-one fashion, whatever it was they counted. ${ }^{15}$ This is unlikely to have been true, given the innate capacity to appreciate small quantities, which Mesopotamian peoples shared, ${ }^{16}$ as well as the "bundling relations" between tokens, ${ }^{17}$ which imply the ability to count because quantities like six and ten exceed the range perceptible through the innate ability to appreciate quantity. ${ }^{18}$

The term "token" evoked the type-token distinction of the philosopher Charles Sanders Peirce. ${ }^{19}$ Peircean "tokens" are physical objects, like instances of the let-

${ }^{14}$ Russell, Introduction to Mathematical Philosophy (1920), 3. Schmandt-Besserat used only the first portion of the second sentence, eliding it as follows: "It . . . required many ages to discover that a brace of pheasants and a couple of days were both instances of the number 2" (Schmandt-Besserat, Before Writing Vol. 1 [1992], 187 and How Writing Came About [1992], 111).

${ }^{15}$ I.e., "one-to-one correspondence without a number system" (Schmandt-Besserat, Before Writing Vol. 1 [1992], 187).

${ }^{16}$ The phylogenetic distribution of the number sense means that ancient peoples had the ability to appreciate quantity (Overmann, Material Origin [2019], 45-46). This biological endowment also influences numerical aspects of language, something detectable in Mesopotamian languages; see ibid., 112-30.

${ }^{17}$ In bundling, some amount of tokens of one value were equivalent to and could be exchanged for a single token of the next higher value; debundling reversed the operation. Tokens were unlikely to have been manipulated solely using bundling-debundling, as it would be easier to count them the way coins are counted today-not by exchanging values between quarters, dimes, and nickels, but by scooping up, for example, three quarters, two dimes, and a nickel as equivalent to a dollar. (This should not be interpreted as suggesting that tokens had monetary value; they did not.) Bundlingdebundling would also have involved substituting/simplifying (e.g., analogous to replacing groups of coins with dollars) and organizing tokens by numerical magnitude; both would have been a function of habits acquired with older technologies like fingers and tallies and a practical matter of making information more accessible and intelligible (Ibid., 137-38, 141, 181).

${ }^{18}$ Overmann, Material Origin (2019), 176-77.

${ }^{19}$ Peirce, "Prolegomena" (1906): 506. ter "A" inked in various fonts, while a "type" is a concept that encompasses all such relevant tokens, like the conceptual letter "A." In Schmandt-Besserat's view, tokens were used for accounting without any type, in this case a concept of number: " . . . there are no tokens to express abstractly numbers such as ' 1 ' or ' 10 '. Instead, a particular counter was needed to account for each type of goods: Jars of oil were counted with ovoids, small measures of grain with cones, and large measures of grain with spheres." ${ }^{20}$ Nor could these objects be reduced "to mere instantiations of a type, i.e. to tokens" in the Peircean sense, ${ }^{21}$ since, on Schmandt-Besserat's interpretation, they were instead meaningful as representations of specific commodities. Schmandt-Besserat hypothesized that the emergence of writing marked the conceptual leap from the concreteness of tokens to an abstract concept of number; this was manifest as writing quantity and commodity separately, where tokens had conjointly encoded both as differences of shape, size, and quantity. ${ }^{22}$

Damerow similarly drew upon Russell's work, focusing on the set-theoretical paradox that had led Russell to create his theory of logical types, ${ }^{23}$ a logical paradox in set membership that Damerow found to have implications for cognitive structures. ${ }^{24}$ Damerow saw token-based accounting as involving concrete numbers and the emergence of writing as enabling the development of abstract or "second-order" numbers, ${ }^{25}$ thereby differentiating "material means" from "conceptual structures" 26 but ignoring the materiality of writing. He also anchored his use of the terms

${ }^{20}$ Schmandt-Besserat, Before Writing vol. 1 (1992), 6. SchmandtBesserat initially applied the terms "abstract" and "concrete" to writing, not tokens: "Hypotheses about the origin of writing generally postulate an evolution from the concrete to the abstract: an initial pictographic stage that in the course of time and perhaps because of the carelessness of scribes becomes increasingly schematic" ("Earliest Precursor" [1978]: 50). Neurological reasons why written characters lose depictiveness are discussed in Overmann, "Beyond Writing" (2016): 289-90 and Material Origin (2019), 187-94.

${ }^{21}$ Schlaudt, "Type and Token" (2020): 633.

22 In "Grasping the Concept" (2010) and How Things Shape the Mind (2013), 106-16, Malafouris sees the separate representation of quantity and commodity in writing as bringing forth an abstract concept of number from a concrete one.

${ }^{23}$ Russell, "Theory of Logical Types" (1910); Soames, Dawn of Analysis (2003), 150-57; also see discussion in Overmann, Material Origin (2019), 32-34.

${ }^{24}$ Damerow, Abstraction and Representation (2010), 41-67.

25 Damerow, "Number as a Second-Order Concept" (1996): $139-48$.

${ }^{26}$ Damerow, Abstraction and Representation (2010), 44. 
"abstract" and "concrete" in the work of psychologist Jean Piaget, known for applying his ideas about development in children to entire societies. Piaget too had drawn on work by Lévy-Bruhl, so Damerow's use of Piagetian theory had the unfortunate effect of reinforcing the labels' evolutionary connotations and concomitant underestimation of "primitive" numeracy. ${ }^{27}$ This has lingered as the impression that Mesopotamian numbers, particularly those associated with the Neolithic tokens, were unusually concrete and rudimentary, an interpretation that is not supportable when these complex archaic numbers are compared to modern cultural number systems, particularly those counting no higher than subitizable quantities like two or three. ${ }^{28}$

Neither Schmandt-Besserat nor Damerow ever mentioned the fact (or its implications) that tokens and the first form of writing, the numerical impressions that resembled and were often made with tokens, were nearly identical: as material forms with the same shapes, sizes, and quantities, they differed chiefly in that tokens were manipulable, while impressions were fixed. Protocuneiform numerical notations were highly similar as well, differing mainly in the addition of small pictures used to identify commodities. Beyond postulating that numerical impressions and proto-cuneiform notations marked a sudden conceptual leap to abstract numbers, neither scholar interrogated how or why this might have occurred. Indeed, given the continuity of form between the different numerical technologies and the added innovation of small pictures, perhaps they should have suspected instead that writing signaled the formation of abstract concepts of commodities. In fact, object-specific counting appears to have been practiced long after writing emerged in the mid-to-late fourth millennium BC, since place value, which developed as the second millennium BC began, appears to have functioned to "ease movement between one metrological

27 Piaget, "Logique Génétique" (1928), 194, and Child's Conception (1952); also see criticisms in Chrisomalis, "Evaluating Ancient Numeracy" (2005) and Overmann, Material Origin (2019), 49-53.

${ }^{28}$ Most restricted systems are located toward the ends of the ancient migrations that peopled the continents, a non-random geographic distribution that positions numerical realization and elaboration as demographically informed and differentially timed by global migration (Overmann, Material Origin [2016], 98-102). For Australian and Amazonian examples, see Bowern and Zentz, "Diversity in the Numeral Systems" (2012); Epps, "Growing a Numeral System" (2006). system and another," ${ }^{29}$ which implies counting specified by object type.

Two lasting impressions were produced. First, the emergence of writing is widely believed to have marked or caused a sudden and dramatic change in the way numbers were conceptualized. Second, the Mesopotamian numbers associated with the Neolithic tokens are understood as concrete to an extent that has been thoroughly conflated with emerging numbers that count no higher than two or three. These views, now deeply entrenched, have stymied investigation into the conceptualization process and how and why a conceptual product like numbers might change. As it stands, the situation is unfortunate, not least because the archaeological record of Mesopotamia has significant potential to provide insight into ancient numeracy. Not only does it contain prehistory's first unambiguous numbers, the numerical impressions and such tokens as accompany them, it also has the requisite duration and extent to support cognitive analyses and interpretations, and generate insights with the potential to influence how we understand numbers and their origin and elaboration generally.

Accordingly, it seems time to retire the labels "abstract" and "concrete," for they inaccurately characterize what numbers are as concepts, ${ }^{30}$ incompletely describe the process, mechanisms, and states of conceptual change in numbers, ${ }^{31}$ and evoke outdated concepts of progressive cultural evolution. ${ }^{32}$ As argued here, they also grossly underestimate the cognitive implications of object-specific counting. To remedy this, an ethnographic comparison to a contemporary number system with object-specific counting is offered.

Discarding the labels does not entail discarding the research that generated them. On the contrary, the present analysis necessarily draws upon the careful work of Damerow and his colleagues, especially Robert Englund and Hans Nissen, ${ }^{33}$ in analyzing the

${ }^{29}$ Robson, Mathematics in Ancient Iraq (2008), 16, 75-76.

${ }^{30}$ Overmann, Material Origin (2019), 25-30.

${ }^{31}$ Ibid., 207-27, and "Updating the 'Abstract-Concrete' Distinction" (2018): 13-15.

32 Damerow, "Prehistory and Cognitive Development" (1996); Lévy-Bruhl, Fonctions Mentales (1912) and L'âme Primitive (1927); Piaget, "Logique Génétique" (1928); Schmandt-Besserat, Before Writing Vol. 1 (1992).

${ }^{33}$ E.g., Damerow, "Individual Development" (1988): 143; Damerow and Englund, ATU 2 (1987); Damerow, Englund, and Nissen, "Ersten Zahldarstellungen" (1988); Damerow and Meinzer, "Computertomografische Untersuchung" (1995); Englund, ATU 5 
numerical impressions and proto-cuneiform notations of the Uruk period. These statistical and archaeological analyses attest the numerical meaning of the archaic technologies and provide insight into characteristics like numerical extent and organization. They also attest the numerical meaning of tokens, at least those of the mid-fourth millennium BC associated with bullae, envelopes, and tablets, as originally discerned by Vivian L. Broman, A. Leo Oppenheim, and Pierre Amiet. ${ }^{34}$ What is at issue, however, is how we might understand the number system that has been so carefully recovered, not as an emergent system but as a highly elaborated system whose object-specificity represents a strategy for dealing with the robust use of numbers in the absence of written notations.

Essential to any renovation program are two components. The first is describing the process and mechanisms associated with numerical realization and elaboration in such a way that the notion that numbers "become abstract" and "stop being concrete" at some point is replaced by a nuanced view of conceptual change in numbers, which after all was Damerow's goal. The process and mechanisms have been described as a matter of incorporating material forms whose properties act as proxies for numerical properties, a technological layering systematized by device properties that emerges reliably and predictably from the interaction of cognitive capacities, behaviors, and material forms. ${ }^{35}$ They are discussed

(1994) and "Texts from the Late Uruk Period" (1998); Nissen, "Archaic Texts" (1986); Nissen, Damerow, and Englund, Archaic Bookkeeping (1993).

${ }^{34}$ Broman, Jarmo Figurines (1958); Oppenheim, "On an Operational Device" (1959); Amiet, "Il y a 5000 Ans" (1966): 20-22. Small clay objects dated as early as the ninth and tenth millennia $\mathrm{BC}$ have been categorized as "tokens" (Schmandt-Besserat, Before Writing vol. 2 [1992]; the expanded dataset of Overmann, Material Origin [2019] includes tenth-millennium material from Moore and Tangye, "Stone and Other Artifacts" [2000]). However, before the mid-fourth millennium $\mathrm{BC}$, no tokens are accompanied by the corresponding numerical impressions that might attest their numerical meaning. While their shapes and sizes may be suggestive, form is not dispositive of purpose, and there are no reliable methods or criteria for diagnosing the social purpose of unaccompanied tokens in ambiguous find contexts; see criticisms in Englund, "Review: Denise Schmandt-Besserat, How Writing Came About" (1998); Friberg, "Preliterate Counting" (1994); Lieberman, "Of Clay Pebbles" (1980); Michalowski, "Review: Tokenism" (1993); Oates, "Early Writing" (1993); Shendge, "Use of Seals" (1983); Zimansky, "Review of Denise Schmandt-Besserat's Before Writing" (1993).

${ }^{35}$ Overmann, "Constructing a Concept" (2018): 468-77, Material Origin (2019), 207-27, and "Updating the 'Abstract-Concrete' Distinction" (2018): 13-15. briefly in the concluding section, for the use of material forms like tokens for counting was a crucial difference between Mesopotamia and Polynesia.

The second renovationist component is gaining insight into what Mesopotamian numbers would have been like as they changed, ideally in such a way that the impression that they were unusually concrete and rudimentary in the Neolithic is dislodged. Toward this end, the focus here is on understanding the numbers used with tokens when writing first emerged: the early Uruk period when the numerical meaning of tokens becomes visible to modern eyes through their assemblages with numerical impressions of corresponding shapes, sizes, and quantities, and the proto-cuneiform numerical notations and labels that followed. For this purpose, I compare Mesopotamian numbers to those of Polynesia, whose cultural number system is geographically, temporally, culturally, linguistically, and historically distinct from that of Mesopotamia. The analysis capitalizes on key characteristics of Polynesian numbers, particularly object-specific counting, polyvalence (the ability to assume different numerical values), and contextdependent value, to understand similar properties in Mesopotamian numbers.

\section{An Ethnographic Comparison}

On studying the traditional number systems of Polynesia, someone familiar with the Neolithic tokens used for counting in Mesopotamia might well experience déjà vu. Take, for example, the number systems of Tonga, a Polynesian nation whose mid-Pacific landmass is an archipelago colonized some 3,000 years ago by settlers who spoke an Austronesian language (see Fig. 1). ${ }^{36}$ The Tongan language has a general counting sequence used to count most things and several specialized sequences for counting items like sugarcane, fish, yams, and coconuts $^{37}$-just like the Neolithic tokens and their direct successors, the numerical impressions and protocuneiform notations of the Uruk period, had a general system for counting most discrete objects and specialized systems for counting things like grain, fish, and dairy products. ${ }^{38}$ And, just like the archaic Mesopotamian

\footnotetext{
${ }^{36}$ Guérin, "Oceanic Subgroup” (2017); Rieth and Cochrane, “Chronology of Colonization" (2018).

37 Bender and Beller, “Counting in Tongan” (2007): 219-22.

${ }^{38}$ Nissen, Damerow, and Englund, Archaic Bookkeeping (1993), 28-29, Fig. 28.
} 


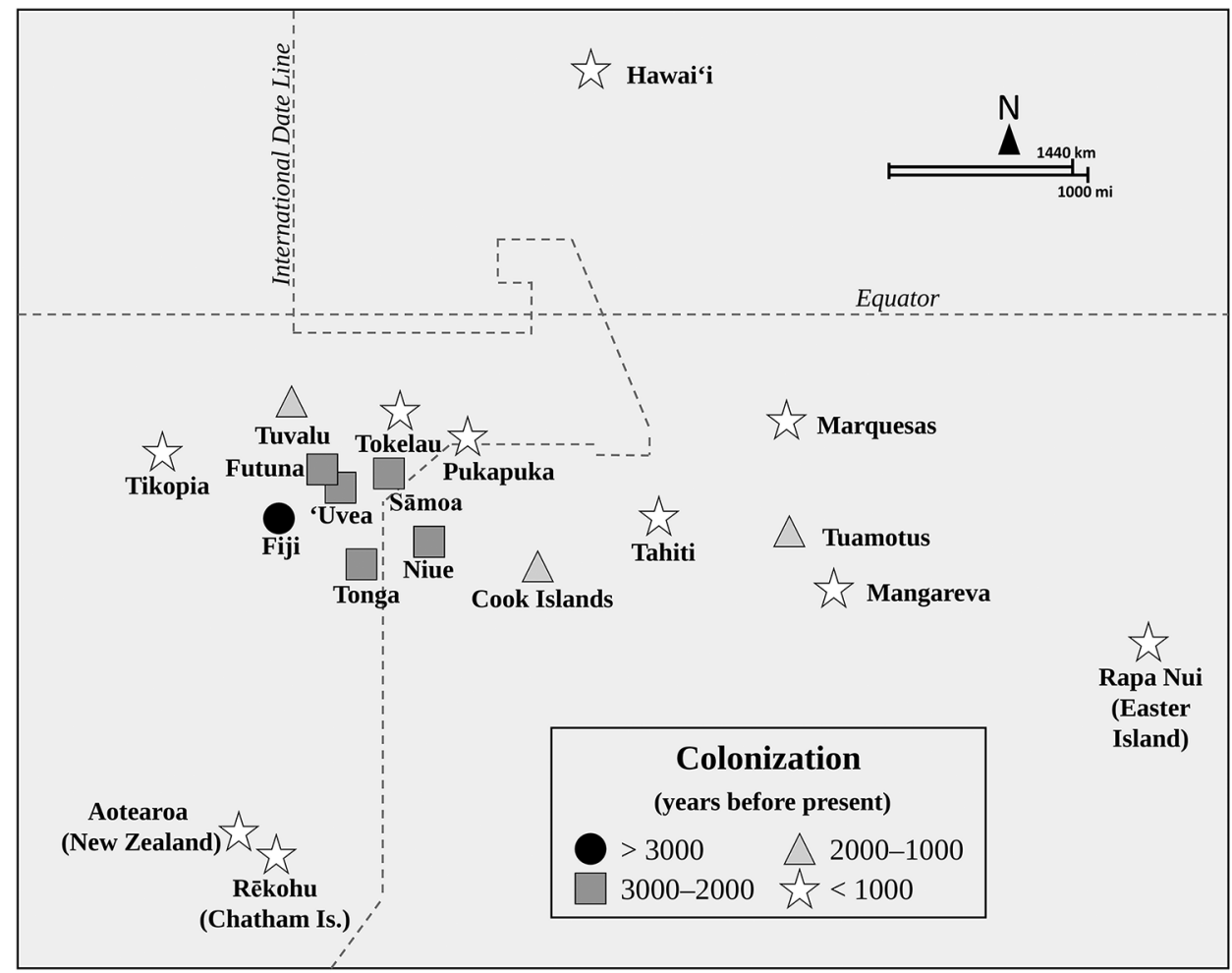

Figure 1-Schematic Map of Polynesian Colonization. Polynesia is the region of the Pacific Ocean bounded by Hawaici, Rapa Nui (Easter Island), and Aotearoa (New Zealand). Tikopia, a Polynesian outlier, is culturally Polynesian but geographically located in Melanesia. Nukuoro, a Polynesian outlier in Micronesia, is not shown; it would lie slightly beyond the figure's upper left side. Fiji, which is Melanesian, is linguistically related to the extent it is used to anchor the Polynesian language family in relational analyses. The islands, languages, and dialects mentioned in the text and shown in the figure reflect the historical evidence and the study's focus on numerical elaboration in the central and peripheral portions of Polynesia. Date ranges were adapted from Rieth and Cochrane, "Chronology of Colonization" (2018), 5-14, Table 7.1.

counting sequences did, ${ }^{39}$ the multiple Tongan counting sequences followed specific patterns in their composition; shared a common term for the smallest unit, whose numerical value could change; used polyvalent terms with contextual numerical value; conjoined the representation of quantity and commodity; and were relative scales of value (see Fig. 2 and discussion throughout).

There is another reason for feeling déjà $v u$. Like the token-based accounting of the Neolithic, ${ }^{40}$ Polynesian numbers have been interpreted as concrete: "Distinct number systems for certain objects within the same language seem to reveal a lack of abstract thinking and are therefore often taken as cognitively deficient." ${ }^{\text {41 }}$ Such interpretations have employed a relatively straightfor-

${ }^{39}$ Ibid.

${ }^{40}$ See e.g., Schmandt-Besserat's (1992) publications Before Writing and How Writing Came About, and Damerow's (1996) publications "Number as a Second-Order Concept" and "Prehistory and Cognitive Development."

${ }^{41}$ Beller and Bender, "Cognitive Advantages" (2005): 214. ward distinction between "concrete" and "abstract": numbers are concrete if they are "applied to particular objects, as peaches, pounds, [or] yards," and they are abstract when they are not, as in the expression "two and three are five." ${ }^{42}$ As thus narrowly defined, ${ }^{43}$ the distinction hinges on two things: whether or not numbers are conceived as objects or entities in their own right (the property of entitivity), rather than as properties of quantity or collections of objects, and whether

42 Thomson, Practical Arithmetic (1846), 261.

43 The term abstract can also have four other meanings: the possible metaphysical status of numbers as intangible, invisible entities, the view of mathematical realism; fidelity in depiction, as in art, the sense in which Schmandt-Besserat first used the term ("Earliest Precursor" [1978]: 50); purpose, the knowledge for knowledge's sake of Greek theoretical mathematics but not Babylonian applied mathematics (Høyrup, In Measure, Number, and Weight [1994], 23-43); and purity, as in something that becomes distilled or rarified. See also the discussion in Overmann, "Updating the 'Abstract-Concrete' Distinction" (2018): 6-9. 
numbers relate to each other or to the objects they count (the property of relatedness).

In 2007, an analysis of the Tongan number systems reached an unexpected conclusion: the specialized counting sequences, rather than being "older and less efficient than the general one," 44 were derived from it and, moreover, functioned as cognitively efficient tools for mental calculation. In 2020, a subsequent analysis of Polynesian numbers reconstructed the traditional counting method that both explained and unified the general and specialized sequences found throughout the region. ${ }^{45}$ Building upon this work, the analysis presented here compares and contrasts the counting sequences of Polynesia and Mesopotamia to see whether similar insights might be realized for the ancient numbers.

The material is organized as follows: first, Polynesian general and specialized counting sequences are described in terms of properties like polyvalence, context-dependent value, and relations; the method of counting that influenced these properties; and the implications for mental calculation. These insights are then used to examine archaic Mesopotamian numbers as represented by tokens, numerical impressions, protocuneiform notations, and cuneiform numbers, focusing on proto-cuneiform notations as the technology providing the most detailed insight into Mesopotamian object-specific counting. The article concludes by examining the nature of number concepts and numerical thinking generally and the role of material forms in them, particularly in highly elaborated but unwritten number systems.

Comparing ancient number systems to living ones has the potential to open new windows on extinct handiwork. Certainly, while the dozen or so proto-cuneiform number systems have long been recognized as specialized and derived, ${ }^{46}$ the idea that they may have also represented mental faculty with abstract number concepts is a new perspective on their cognitive significance, one that strongly counters their historical interpretation as particularly concrete and rudimentary. The converse is perhaps less intuitive, since the goal of comparing living number systems to ancient ones is not to position the former as some kind of prehistoric relic, but rather to celebrate the pragmatic inventiveness and cognitive

${ }^{44}$ Bender and Beller, "Counting in Tongan” (2007): 214.

${ }^{45}$ Overmann, "Curious Idea" (2020): 69-73, and "Counting by "Elevens'”' (2021).

${ }^{46}$ E.g., Nissen, Damerow, and Englund, Archaic Bookkeeping (1993). dexterity of creative peoples in vibrant societies across time and space, as well as capitalize on opportunities for generating new insights into the uniquely human aptitude for numbers.

There is a practical benefit to be realized as well. Traditional Polynesian number systems were documented observationally and linguistically, types of evidence largely unavailable for ancient numbers. Observational insight into ancient behaviors like counting is precluded by the lack of contemporary descriptions and depictions. This necessitates that they be reconstructed inferentially from evidence like scribal errors, notational fixedness, and the lack of recording interim steps that imply tokens were used for calculating. ${ }^{47}$ The semasiographic nature of numerical notations means that the phonetic values of ancient number-words must be reconstructed, often incompletely, from evidence like phonographic writing (which for Sumerian numbers began to emerge centuries after writing $\mathrm{did}^{48}$ ) or comparative vocabulary (which is precluded for isolated languages like Sumerian and Elamite). This has forced a reliance on numerical notations, forms that lack pronunciation clues and which thus cannot reveal whether and how polyvalent terms might have been distinguished morphologically. As a result, analyses of ancient numbers have necessarily been based on archaeological and textual data, yielding interpretations that observational and linguistic insights can challenge.

\section{Polynesian Counting}

Polynesia is a roughly triangular region of the southcentral Pacific Ocean bounded by Hawai'i to the north, Rapa Nui (Easter Island) to the east, and Aotearoa (New Zealand) to the south (Fig. 1). It contains over a thousand islands, mostly volcanic but some created by continental submergence. The oceanic migration that colonized the islands has been traced archaeologically, linguistically, and genetically to maritime cultures originating in Taiwan and, ultimately, China. ${ }^{49}$ Colonization of central Polynesia began nearly 3,000 years ago from Melanesian island groups in the vicinity of Fiji; it continued eastward into the Cook Islands and

\footnotetext{
${ }^{47}$ Høyrup, Lengths, Widths, Surfaces (2002), 73, 195-96; Overmann, Material Origin (2019), 198-99.

${ }^{48}$ Damerow, “Individual Development” (1988): 144.

${ }^{49}$ Chambers, "Genetics and Origins" (2013); Guérin, "Oceanic Subgroup" (2017); Hurles et al., "Untangling Oceanic Settlement" (2003); Lipson, "Population Turnover" (2018).
} 
Tuamotu Archipelago before expanding as far as Hawai'i, Rapa Nui, and New Zealand, the region's northern, eastern, and southern peripheries, over the last thousand years. ${ }^{50}$ The few westward settlements like Tikopia and Nukuoro are known as outliers, culturally Polynesian but geographically located in Melanesia or Micronesia. Relations between Polynesian languages and dialects closely track with this geographic settlement pattern. ${ }^{51}$ Beyond its western border, Polynesia developed in relative isolation; ${ }^{52}$ this made it an ideal "laboratory" for studying cultural developments like numbers, especially in its northern, eastern, and southern regions. ${ }^{53}$

European exploration of the Pacific began in the marginal seas on its western side, with expeditions reaching the Moluccas in 1509, Malacca in 1511, and southern China in $1513 .{ }^{54}$ In 1513, the eastern side of the Pacific was sighted from the Isthmus of Panama by Vasco Núñez de Balboa, who named the ocean Mar del Sur ("South Sea"), an appellation persisting in terms like "South Sea islands." In 1520, Ferdinand Magellan would give the ocean a different name, Mar Pacifico ("Peaceful Sea"), memorializing its comparative calm after the difficult passage around the tip of South America; he would reach the Polynesian Tuamotus in 1521. Spanish, Dutch, English, and French expeditions to Polynesia soon followed. These explorers, and the naturalist scientists who accompanied them, documented many aspects of Polynesian languages and culture, including their numbers, providing a limited and often imperfect insight into traditional Polynesian counting practices and number-words. ${ }^{55}$

${ }^{50}$ Rieth and Cochrane, "Chronology of Colonization" (2018).

${ }^{51}$ Lynch, Ross, and Crowley, Oceanic Languages (2002).

${ }^{52}$ Kirch, Evolution of the Polynesian Chiefdoms (1984), 3.

${ }^{53}$ Suggs, Archaeology of Nuku Hiva (1960), 194.

${ }^{54}$ Lach, Asia in the Making of Europe (1994); Ricklefs, History of Modern Indonesia (1981).

${ }^{55}$ Early observers faced significant linguistic and cultural barriers. They were generally untrained in the wide range of fields in which they were expected to record data. Their descriptions tended to lack detail and were biased by the prevalent Eurocentric view of traditional practices as primitive. They could also misunderstand what they saw, sometimes hilariously so: for instance, the Spanish attempted to elicit number-words by showing written Western numerals to the Rapa Nui islanders (González de Haedo, Voyage of Captain Don Felipe Gonzalez [2007], 110); the English thought Māori numbers were vigesimal (Chamisso, "Du Grand Océan" [1825], 27); the French said that Māori counted by elevens (Balbi, "Observations sur la Classification" [1826], 256-57); and the French collected Tongan words purported to be numbers that were instead salacious, if not
The homogeneity of counting practices and numberwords throughout the region was often remarked upon. ${ }^{56}$ Some linguistic differences were also noted, both as local changes in pronunciation and as differences in numerical vocabularies. In some cases, the names for the higher powers were replaced by distinct lexemes (e.g., the unique term for $10^{3}$, piere, in Rapanui ${ }^{57}$ ), and in others, their order in the exponential sequence differed (e.g., mano was $10^{4}$ in Tongan but $10^{3}$ in Hawaiian $\left.^{58}\right)$. The numeral classifiers ${ }^{59}$ observed in western Polynesia dwindled and disappeared in the central and peripheral regions, where languages developed object-specified counting. ${ }^{60}$ In Polynesian languages, numeral classifiers and object-specified counting are linked, as both count different types of objects differently, and both can multiply numerical values. ${ }^{61}$ As settlement expanded from western Polynesia into the region's center and peripheries, counting simplified

obscene (Labillardière, "Appendix: Vocabulaire" [1799], 50; Martin, Account of the Natives [1818], 370-71). However limited or flawed, the historical observations nonetheless provide valuable and unique insight into traditional Polynesian numbers before they were much altered by exposure to Western concepts and practices.

${ }^{56}$ See e.g., Cook, Voyage Towards the South Pole (1777), table facing 364; Forster, "Remarks on the Human Species" (1778), table facing 284; Hale, United States Exploring Expedition (1846), 62-63; Lesson and Garnot, Voyage Autour du Monde (1826), 84.

${ }^{57}$ Fuentes, Diccionario y Gramática (1960), 617; Roussel, Vocabulaire de la Langue (1908), 219.

${ }^{58}$ Clark, "Hawaiian Method" (1839): 93; Martin, Account of the Natives (1818), 369; Rabone, Vocabulary of the Tonga Language (1845), 166. Note that exponential values were also shifted upward by a factor of four in Hawaici but not in Tonga.

${ }^{59}$ Numeral classifiers are "special morphemes which only appear next to a numeral, or a quantifier. They may categorize the referent of a noun in terms of its animacy, shape, and other inherent properties" (Aikhenvald, Classifiers [2000], 3). They have been associated with the abstract/concrete distinction: Lévy-Bruhl thought classifiers marked the absence of an abstract concept of number (Fonctions Mentales [1912], 219-30). Here they are taken as a way of marking commodity in the absence of written notations (or other material forms of recording). Also see the discussion of numeral classifiers in regard to the abstract-concrete distinction in Valério and Ferrara, "Numeracy at the Dawn of Writing" (2021): 3-6.

${ }^{60}$ Bender and Beller, "Numeral Classifiers" (2006): 393.

${ }^{61}$ Ibid.: 399. So-called power classifiers "indicate a precise value-either the base of the number system or one of its powersthat serves as a factor for the adjoined numeral. As power classifiers replace other classifiers, they typically indicate the new counting unit independently of the object concerned. A few classifiers, however, adopt both a classifying and a multiplying function: they have a precise value and are restricted to certain objects indicating, for instance, 'tens of coconuts'” (ibid., "Numeral Classifiers" [2007]: 824). 
and dominant patterns emerged, shifting the decimal powers upward by factors of two or four. For example, one rau meant 100 in Tahitian but 200 in Māori and 400 in Hawaiian. ${ }^{62}$ Simplified, dominant counting sequences would be consistent with counting in an initially more limited fashion in newly established colonies, in terms of both smaller quantities and fewer types of goods. ${ }^{63}$

Notations, whether for numbers or language, were unknown prior to European contact, though the Rongorongo script discovered on Rapa Nui in the nineteenth century is a possible exception. Rongorongo has not been satisfactorily translated, ${ }^{64}$ but is thought to have perhaps functioned as a mnemonic device for chants. ${ }^{65}$ Whether its invention predated European contact remains unestablished, and the idea of writing is known to have been introduced in Rapa Nui by the Spanish in the late eighteenth century, specifically as numbers. ${ }^{66}$

\section{Characteristics of Polynesian Numbers}

In their organization, structure, vocabulary, and counting methods, the Tongan number systems are often illustrative of Polynesian number systems generally. Other Polynesian number systems will be referenced as well, noting that while the method of counting by sorting remained the same, the associated powers were shifted upward in some areas, as previously noted, and a binary variant of counting-by-sorting developed in Mangareva. ${ }^{67}$ As was noted earlier, the Tongan number systems included a general sequence for counting most objects and multiple specialized sequences used to count specific types of objects (Fig. 2).68 The general counting sequence had a standard decimal organization and regular exponential structure. ${ }^{69}$ Object-specific

${ }^{62}$ Best, "Māori Numeration" (1906): 165; Chamisso, Über Die Hawaiische Sprache (1837), 57; Jaussen, Grammaire et Dictionnaire (1861), 24.

${ }^{63}$ Overmann, "Counting by 'Elevens" " (2021): 7-8.

${ }^{64}$ Davletshin, "Numerals and Phonetic Complements" (2012): 243.

${ }^{65}$ Fischer, Rongorongo: The Easter Island Script (1997), 163.

${ }^{66}$ González de Haedo, Voyage of Captain Don Felipe Gonzalez (2007), 109-110; Métraux, "Numerals from Easter Island" (1936): 253.

${ }^{67}$ Overmann, “Curious Idea" (2020): 72, Figure 4.

${ }^{68}$ Bender and Beller, "Counting in Tongan" (2007): 218-22.

${ }^{69}$ In mathematics, exponents are the powers to which a given number is raised, typically the base of the number system. For example, in a decimal number system, the base number is ten, and counting was likewise decimal but took as its basic unit a pair, two items counted together as a single item. The specialized Tongan counting sequences for counting fish, yams, and coconuts introduced a new term for the bundle created by counting ten pairs, giving it a name glossed as the English word score, chosen to reflect its numerical value of twenty. The introduced term affected how higher bundles were counted but not the resultant numerical values: for example, one score of fish and ten pairs of sugarcane both meant twenty items (compare Figs. 2b and 2c, $10^{1}$ column).

Object-specific counting was used to count abundant objects with particular cultural value (e.g., associated with subsistence and redistribution) that were enumerated often and to significant quantities. ${ }^{70} \mathrm{Im}$ portantly, counting large quantities of objects was more efficient when objects were handled two at a time, while continuing to treat them as a single unit meant the counting sequence was unaltered. That is, rather than counting two, four, six, eight, as we might count with pairs, counting remained one, two, three, four, etc. Counting collectively with pairs had the effect of shifting numerical values upward by a factor of two, such that ten counted with pairs had the numerical value twenty. Besides Tonga, this upward shift was characteristic of numbers in Rarotonga (Cook Islands), Tahiti, New Zealand, Mangareva, and the northwestern Marquesas. $^{71}$ Similarly, four-based counting shifted numerical values upward by a factor of four, such that ten counted with a unit of four had the numerical value forty; this was documented in Hawaici, the southeastern Marquesas, and Mangareva. ${ }^{72}$ Counting collectively created side-by-side counting sequences: the general sequence for items counted singly and objectspecific sequences for items counted in pairs (found throughout Polynesia), fours (prevalent in the northern and eastern peripheries, and documented in New

the powers of ten are one $\left(10^{\circ}\right)$, ten $\left(10^{1}\right)$, hundred $\left(10^{2}\right)$, thousand $\left(10^{3}\right)$, ten thousand $\left(10^{4}\right)$, hundred thousand $\left(10^{5}\right)$, million $\left(10^{6}\right)$, etc., introducing new productive terms (Sizer, "Base and Subbase" (2004)). Each exponent is ten times the previous one, the exponential structure of decimal numbers.

${ }^{70}$ Bender and Beller, "Counting in Tongan” (2007): 227.

${ }^{71}$ Buzacott, Te Akataka (1854); Jaussen, Grammaire et Dictionnaire (1861); Best, "Māori Numeration" (1906); Janeau, Essai de Grammaire (1908); Lemaître, "Systèmes de Numération” (1985).

${ }^{72}$ Jaussen, Grammaire et Dictionnaire (1861); Kanepuu, "Ka Helu Hawaii” (1867); Lemaître, “Systèmes de Numération” (1985). 


\begin{tabular}{|c|c|c|c|c|c|c|}
\hline \multirow{3}{*}{ (a) General } & $10^{5}$ & $10^{4}$ & $10^{3}$ & $10^{2}$ & $10^{1}$ & $10^{0}$ \\
\hline & kilu & mano & afe & teau & honogofulu: & unit \\
\hline & 100,000 & 10,000 & 1000 & 100 & 10 & Single \\
\hline \multirow{4}{*}{ (b) Sugar cane } & & & $10^{3}$ & $10^{2}$ & $10^{1}$ & $10^{0}$ \\
\hline & & & afe & teau & tetula & unit \\
\hline & & Pairs & 1000 pairs & 100 pairs & 10 pairs & 1 pair \\
\hline & & Pieces & 2000 & 200 & 20 & 2 \\
\hline \multirow{5}{*}{ (c) Fish; yams; } & & & $10^{3}$ & $10^{2}$ & $10^{1}$ & $10^{0}$ \\
\hline & coconuts & & teau & tefuhi ${ }^{1}$ & tekau ${ }^{2}$ & unit \\
\hline & & Scores & 100-score & 10-score & 1 score & 1 pair \\
\hline & & Pieces & 2000 & 200 & 20 & 2 \\
\hline & & & & $\begin{array}{l}\text { 1 used with yams; } \\
\text { tefua is used with } \\
\text { coconuts, kau ikace } \\
\text { honogoululu with fis }\end{array}$ & $\begin{array}{l}{ }^{2} \text { used with yams } \\
\text { and coconuts, kau } \\
\text { ika'e taha is used } \\
\text { with fish. }\end{array}$ & \\
\hline
\end{tabular}

Figure 2-Tongan General and Specialized, Derived Counting Sequences. In Tonga, a single method of counting (Figure 3a) was differentiated by whether the basic unit was a single or pairs, the presence or absence of higher bundling, and morphological changes encoding the commodity being counted (see Table 2). (a) The general system used to count most objects was a decimal system with regular base-10 exponents. (b) The system for counting sugarcane was likewise regularly decimal but took a pair (two pieces counted together) as its basic unit. This "collective counting" doubled the resultant numerical values, relative to the general system from which it was derived, as each unit was numerically worth two. (c) The system for counting fish, yams, and coconuts took the pair as its basic unit, but bundled them in groups of ten to create scores (numerically worth 20), which were then counted by tens as 10-scores, 100-scores, etc. Like the system for counting sugarcane, numerical amounts were shifted upward by a factor of two, relative to the general system. Number-words also differed to specify the item being counted (see the numbered notes below the units $10^{1}$ and $10^{2}$; also see Table 2). The method of visualization was based on that of Nissen, Damerow, and Englund, Archaic Bookkeeping (1993), 28-29, Figure 28; the data visualized were derived from multiple sources, particularly Bender and Beller, "Counting in Tongan” (2007): 222, Table 2.

Zealand), and eights (Mangareva, which lies toward the eastern periphery).

Numerical relations within any particular counting sequence, general or specified, included those of accumulation and grouping. Accumulation allowed items to be counted sequentially (i.e., the Polynesian equivalents of one, two, three, etc.). Grouping created intrasystem relations in which, for example, an afe's worth of objects was equivalent to ten tean of them. Equivalences of value between the general and specified sequences linked them and created inter-system relations, as for example, an afe's worth of objects counted with a specialized sequence was numerically equivalent to twice that amount counted with the general sequence. ${ }^{73}$ Together, these relations allowed numerical values to be expressed by doubling. In Māori, one of the two Polynesian languages of New Zealand, the number 240 was expressed as kotabi ran ma rua (topu)-literally, one hundred and two [tens] (doubled) $)^{74}$; the amount was understood as doubled, an implicit binary factor-

${ }^{73}$ Bender and Beller, "Counting in Tongan" (2007): 220, Table 2.

${ }^{74}$ Best, "Māori Numeration" (1906): 179. ability (i.e., the ability to be doubled, as in the present case, or halved in reverse, if used) because the items were counted in pairs. ${ }^{75}$ Note the implied place that valued two as ten each; this is further discussed below in conjunction with the counting method, its realization of exponential structure, the practice of rounding to the most significant digits, and the relative scale of value (the idea that an exponent's value is derived from those adjacent to it, rather than being anchored by the decimal point).

As can also be seen in Figure 2, the lowest unit in Tongan counting sequences could change numerically from one to two, contextual value that depended on what the item was, which determined whether it would be counted singly or in pairs. Terms for bundled values

\footnotetext{
75 The interesting question is whether terms like 240 represented mental doubling (e.g., like we use in converting two dozen to the number twenty-four) or on-demand generation (e.g., like we do in expressing and understanding numbers we have never encountered before, like fourteen million, nine hundred sixty-eight thousand, seven hundred and eighty-two). While either would represent an impressive mental faculty with numbers, the latter suggests a greater frequency of use, consistent with lexicalization.
} 
like teau were also shared between counting sequences but took their value from the lowest unit of counting. The term with the greatest number of possible values was team, which meant 100 objects counted with the general sequence, 200 (100 pairs) when referring to sugarcane, or 2000 (one 100-score, with each score worth 20 each) with coconuts or yams. ${ }^{76}$ For Mesopotamia, this same quality has been used to argue that numbers were concrete, ${ }^{77}$ the idea being that polyvalence meant a number like ten was not understood as having the same numerical value across counting sequences. ${ }^{78}$ In the Tongan and other Polynesian counting sequences, this was demonstrably false, since polyvalent terms like tean and equivalence relations like twenty singles, ten pairs, and five fours were understood implicitly and acted to link the different counting sequences.

Beyond recognizing intra- and inter-system relations and polyvalent, contextual value, Polynesians were adept at combining the different counting sequences to express numerical amounts in language. Traditional Hawaiian numbers, which were decimal but assumed a unit of four, could be expressed in five ways: in the four-based decimal system; as standard decimal numbers; with pair-counting, as in the term for twenty, iwakalua $; 7^{79}$ by irregular terms like the word for thirty,

${ }^{76}$ Bender and Beller, "Counting in Tongan" (2007): 220, Table 2.

${ }^{77}$ E.g., Schmandt-Besserat, Before Writing vol. 1 (1992) and How Writing Came About (1992); also see Damerow, "Number as a Second-Order Concept" (1996) and "Prehistory and Cognitive Development" (1996).

${ }^{78}$ Chrisomalis has compellingly argued against the idea that Mesopotamian peoples were particularly incompetent or concrete in their conceptualization of numbers: "If . . . polyvalence and context-dependence imply an absence of abstract number concepts, then paradoxically, the quasi-literate Uruk accountants would be less numerate than the average Sumerian who did not use texts, only number words" (Chrisomalis, "Evaluating Ancient Numeracy" [2005]: 4); "the accountants and scribes who used [tokens and numbers] were able to manage complex administrative tasks, and it is implausible that they did not recognize that ' 8 sheep' and ' 8 bushels of grain' had something in common" (Chrisomalis, "Cognitive and Cultural Foundations" [2009]: 502); and "in order for these contextdependent numerals to represent a stage of 'archaic arithmetic' in the evolution of numeration, ... we would expect similar systems to be present in other civilizations. Yet nothing of the sort can be found in Shang, Predynastic Egyptian, or Zapotec inscriptions, the other early and independently invented systems" (Chrisomalis, Numerical Notation [2010], 237). Also see discussion in Overmann, Material Origin (2019), 162-64.

79 The Hawaiian word for twenty, iwakalua, which means nine and two, is consistent with counting with pairs: The first nine pairs kanakolu; or as some combination of these choices (see Table 1) ${ }^{80}$ Rather than confusion or concreteness, this variability of linguistic expression displayed a considerable command of the highly elaborated numerical relations, just as Māori expressions like 240 did. Indeed, this expressive variability implies a faculty in mentally manipulating numerical relations that is the very antithesis of concreteness.

Polyvalent terms necessitated that the context of use be indicated in some fashion so that numerical values were correctly expressed and interpreted. The intended counting sequence was identified linguistically through grouping terms and morphological changes (see Table 2): kau, a group analogous to the English term score, was only used when counting fish, yams, or coconuts; tefubi and tefua, both words for 10-score, differentiated whether yams or coconuts were meant. ${ }^{81}$ Conversely, linguistic marking served to encode the type of object being enumerated, the grouping relations used, and the exponential register intended. This object-specific marking conjoined commodity and quantity in a way that evokes the same conjoinment in the Neolithic tokens and Uruk-period numerical impressions of Mesopotamia.

\section{Traditional Polynesian Counting}

Rather than being dissociated or separately developed, the different counting sequences were derived from a single method of counting. This method, attested throughout Polynesia by behavioral observations, numerical structure, and language, set aside every tenth item to act as a counter (see Figure $3 \mathrm{a})^{82}$ : in Tikopia, "in counting grains of rice [the informant] reckoned nine and then put aside the tenth grain, and so on. Afterwards he reckoned up the tenth grains to reckon the hundreds." ${ }^{83}$ In New Zealand, European observers misunderstood the practice of putting aside one of every ten as counting by "elevens." ${ }^{84}$ The practice has

(or 18 items) are counted into the heap of items counted, and the last pair (two items) is reserved as a counter for the next round (Overmann, "Curious Idea" [2020]: 71).

${ }^{80}$ Clark, "Hawaiian Method" (1839): 93 and Ellis, Narrative of a Tour (1826), 502.

${ }^{81}$ Bender and Beller, "Counting in Tongan" (2007): 220, Table 2.

${ }^{82}$ Overmann, "Curious Idea" (2020): 69-73.

${ }^{83}$ Durrad, "Tikopia Vocabulary" (1913): 146.

${ }^{84}$ Conant, Number Concept (1896), 122-23. It is indeed possible to count by setting aside every eleventh item as a tally; this 
Table 1-Flexible Expressions of Hawaiian Numbers. Numerical expressions in the traditional Hawaiian number system, showing some documented exceptions (highlighted in bold font) to regular four-based decimal forms. Numbers under 40 (the productive term ten fours) could be expressed in four-based decimal form (e.g., ten would be two fours and two ones, as in the first form for 85,650 ) or standard decimal form (e.g., ten, as in the second form for 85,650 ). Such forms suggest that beyond simply recognizing amounts like twenty singles, ten pairs, and five fours as equivalued, Hawaiians combined the different counting sequences to achieve succinctness of expression, in the process displaying a considerable command of the highly elaborated numerical relations. Key: iwakalua, 20 (lit., 9 and 2); kabi, 1; kanaba, 40 (lit., ten fours); kanakolu, 30 (ten threes?); kauna, unit of four; kini, 40,000; kolu, 3; law, 400; lima, 5; lua, 2; mano, 4000; umi, 10. Values, expressions, and numerical meanings from Clark, "Hawaiian Method" (1839): 93; Ellis, Narrative of a Tour (1826), 479.

\begin{tabular}{|c|c|c|}
\hline Value & Expression and Numerical Meaning & Notes \\
\hline 50 & $\begin{array}{l}\text { kanaha me ka umi } \\
1(40)+1(10)\end{array}$ & $\begin{array}{l}\text { Four-based counting combined with } \\
\text { decimal counting }\end{array}$ \\
\hline 60 & $\begin{array}{l}\text { akahi kanaha me ka iwakalua } \\
1(40)+1(20)\end{array}$ & $\begin{array}{l}\text { Four-based counting combined with } \\
\text { pairs counting }\end{array}$ \\
\hline 70 & $\begin{array}{l}\text { akahi kanaba me ke kanakolu } \\
1(40)+\mathbf{1}(\mathbf{3 0}) \\
\text { hookabi kanaba me na umi ekolu } \\
1(40)+\mathbf{3}(\mathbf{1 0})\end{array}$ & $\begin{array}{l}\text { Four-based counting combined with } \\
\text { an irregular term } \\
\text { Four-based counting combined with } \\
\text { decimal counting }\end{array}$ \\
\hline 80 & $\begin{array}{l}\text { elua kanaba } \\
2(40)\end{array}$ & Four-based counting \\
\hline 100 & $\begin{array}{l}\text { elua kanaha me ka iwakalua } \\
2(40)+1(20)\end{array}$ & $\begin{array}{l}\text { Four-based counting combined with } \\
\text { pairs counting }\end{array}$ \\
\hline 600 & $\begin{array}{l}\text { bookabi lau a me na kanaha elima } \\
1(400)+5(40)\end{array}$ & Four-based counting \\
\hline 10,000 & $\begin{array}{l}\text { elua mano me na lau elima } \\
2(4000)+5(400)\end{array}$ & Four-based counting \\
\hline 85,650 & $\begin{array}{l}\text { elua kini, hoobaki mano, eha lan, akahi kanaha, elua kauna me alua } \\
2(40,000), 1(4000), 4(400), 1(40), 2(4), 2(1) \\
\text { elua kini, hoobaki mano, eha lau, akahi kanaba me ka umi } \\
2(40,000), 1(4000), 4(400), 1(40)+1(10)\end{array}$ & $\begin{array}{l}\text { Four-based counting } \\
\text { Four-based counting combined with } \\
\text { decimal counting }\end{array}$ \\
\hline 846,248 & $\begin{array}{l}2 \text { lehu, } 1 \text { kini, } 1 \text { mano, } 5 \text { lau, } 6 \text { kanaha, and } 2 \text { kanna } \\
2(400,000), 1(40,000), 1(4000), 5(400), 6(40), 2(4)\end{array}$ & Four-based counting \\
\hline 864,895 & $\begin{array}{l}2 \text { kini, } 1 \text { lehu, } 6 \text { mano, } 2 \text { rau, } 2 \text { kanaha, } 1 \text { umi, and } 5 \\
2(400,000), 1(40,000), 6(4000), 2(400), 2(40), 1(10) \text {, and } 5\end{array}$ & $\begin{array}{l}\text { Four-based counting combined with } \\
\text { decimal counting }\end{array}$ \\
\hline
\end{tabular}

also been documented in Papua New Guinea, where it is used to count yams in groups of six to realize a similarly impressive exponential structure, although there the method is used only with single items, not pairs or fours. ${ }^{85}$

Essentially, commodities were counted by sorting them into separate piles: objects considered as having been counted and objects set aside to represent the count. In the first round, every tenth item set aside as

produces an accurate enumeration, albeit in base 11 rather than base 10. It is unlikely the Polynesians did this, as "elevens" counting fails to yield the relations found throughout the region, wherein terms like twenty singles, ten pairs, and five fours were recognized as equivalent in numerical value and could be exchanged in expressing smaller numbers (see e.g., Table 1).

85 Döhler, Grammar of Komnzo (2018), 16-18; Evans, "Two Pus One" (2009): 331-32; Williams, Papuans of the Trans-Fly (1936), 226-27. Also see Overmann, “Curious Idea" (2020): 76, Figure 5. a counter represented ten of whatever commodity was being counted; in the second round, every tenth item was valued at a hundred; in the third, as a thousand; and so on (see Fig. 3a). Successive rounds created both an exponential structure and an abacus-like device. This device, composed of piles of the commodity being enumerated, was ephemeral, given that the elements regained their status as commodities once counting them had finished. Once exponential registers were formed by sorting commodities into piles, moving items between them would have involved exchanging ten items for one, or one item for ten in reverse, operations reminiscent of the bundling/debundling used with Neolithic tokens. However, there are no historical descriptions of such bundling/debundling operations in Polynesia, perhaps either because the movement of items between exponential registers was simply not remarked, or the size and weight of enumerated commodities like coconuts would have tended to preclude them. 
Table 2-Tongan General and Object-specific Counting. Object-specific counting encoded both the object being counted and the bundles used in counting. For example, tefubi specified pieces of yam, tefua coconuts, both in the quantity glossed as 10-score. Polyvalent terms were understood in context: teau was understood to mean 100 items counted with the general system if it followed hongofulu in sequence; 100 pairs (or 200 items) of sugarcane thatch if it followed tetula in sequence; or one 100-score (or 2000 items) of fish, pieces of yam, or coconuts if it followed, respectively, honogofulu, tefubi, or tefua in sequence. Data from Churchward, Tongan Grammar (1985), 171-89; Rabone, Vocabulary of the Tonga Language (1845); format after Bender and Beller, "Counting in Tongan" (2007): 220, Table 2.

\begin{tabular}{|c|c|c|c|c|c|c|c|}
\hline \multirow[b]{2}{*}{$\mathrm{Nr}$} & \multirow[b]{2}{*}{ General system } & \multicolumn{6}{|c|}{ Derived systems } \\
\hline & & Unit & Sugarcane $^{\mathrm{a}}$ & Unit & Fish $^{\mathrm{b}}$ & Pieces of yam ${ }^{c}$ & Coconuts $^{\mathrm{d}}$ \\
\hline 1 & taba & - & - & - & - & - & - \\
\hline 2 & ua & 1 pair & taba & l pair & taba & taba & taha \\
\hline 3 & tolu & - & - & - & - & - & - \\
\hline 4 & $f \bar{a}$ & 2 pairs & ua & 2 pairs & ua & ua & ua \\
\hline 5 & nima & - & - & - & - & - & - \\
\hline 6 & ono & 3 pairs & tolu & 3 pairs & tolu & tolu & tolu \\
\hline 10 & hongofulu & - & - & - & - & - & - \\
\hline 20 & nofulu & 10 pairs & tetula & l score & taba & tekan & tekau \\
\hline 30 & tolungofulu & - & - & - & - & - & - \\
\hline 40 & fāngofulu & 20 pairs & uangotula & 2 scores & ua & uangakau & uangakau \\
\hline 50 & nimangofulu & - & - & - & - & - & - \\
\hline 60 & onongofulu & 30 pairs & tolungotula & 3 scores & tolu & tolungakau & tolungakau \\
\hline 100 & tean & - & - & - & - & - & - \\
\hline 200 & uangeau & 100 pairs & tean & 1 10-score & bongofulu & tefubi & tefua \\
\hline 300 & tolungeau & - & - & - & - & - & - \\
\hline 400 & fängeau & 200 pairs & uangeau & 210 -scores & nofulu & uangofubi & naofua \\
\hline 500 & nimagean & - & - & - & - & - & - \\
\hline 600 & onongeau & 300 pairs & tolungeau & 310 -scores & tolungofulu & tolungofubi & tolufua \\
\hline 1000 & (taba) afe & - & - & - & - & - & - \\
\hline 2000 & na afe & 1000 pairs & $(t a b a)$ afe & 1100 -score & tean & tean & tean \\
\hline 3000 & tolu afe & - & - & - & - & - & - \\
\hline 4000 & $f a \bar{a} a f e$ & 2000 pairs & wa afe & 2 100-scores & uangeau & uangeau & nangeau \\
\hline 5000 & nima afe & - & - & - & - & - & - \\
\hline 6000 & ono afe & 3000 pairs & tolu afe & 3100 -scores & tolungean & tolungean & tolungean \\
\hline
\end{tabular}

${ }^{a}$ For sugarcane thatch $(a u)$, the numbers one and nine could be preceded by ba an ' $e$ ( $b a$, article; ' $e$ introduced the number and related it to the preceding words) and followed by nga'ahoa (pair of). Two pairs of sugarcane (four items) would be ba an 'e na nga'ahoa (or simply ua). Higher numbers omitted nga'ahoa: Ten pairs (20 items), ha au'e tetula; 100 pairs (200 items), ba an 'e teau; 1000 pairs (2000 items), ba an'e taba afe.

${ }^{b}$ For fish (mata' $i$ ika), the numbers one to nine could be preceded by ba mata' $i$ ika' $e$ and followed by nga'ahoa. Two pairs of fish (four items) would be ha mata'i ika'e na nga'ahoa. Higher numbers were preceded by ha kan ika 'e ( $k a w$, score): Two scores (40 items), ha kan ika 'e ua; 20 scores (400 items), ha kau ika'e nofulu; 200 scores (4000 items), ha kau ika'e nangeau.

'For pieces of yam (konga 'ufi or pulopula), the numbers one to nine could be preceded by ha konga 'ufi' $e$ and followed by nga'ahoa. Two pairs of yam pieces (four items) would be ha konga 'ufi' $e$ na nga'ahoa. Higher numbers were preceded by ha pulopula 'e: Two scores (40 items), ha pulopula 'e uangakaw; 20 scores (400 items), ha pulopula'e uangofubi; 200 scores (4000 items), ha pulopula 'e nangeau.

'For coconuts ( $\mathrm{nin}$ ), the numbers one to nine could be preceded by ba tana' $i$ nin ' $e$ (tana' $i$, pair of). Two pairs of coconuts (four items) would be ba tana' $i$ nin' 'e ua. Higher numbers were preceded by ha nin 'e: Two scores (40 items), ha nin 'e nangakan; 20 scores (400 items), ba niu'e nofua; 200 scores (4000 items), ha niu'e uangeau.

The exponential value of the counters emerged from their literal physical placement in being counted (e.g., an item placed in the pile of hundreds had that value) and the order created by successive rounds of counting (e.g., thousands would be adjacent to and one register higher than hundreds). Any particular exponent was understood through its relation to the previous one from which it was created, as well as the one that would immediately follow it, assuming it were needed (i.e., a pile of counters greater than ten occasioned a subsequent round of counting, while fewer than ten counters did not). Sequential place value was assumed in numerical expressions, as was the case in the Māori example noted earlier for the number 240, 


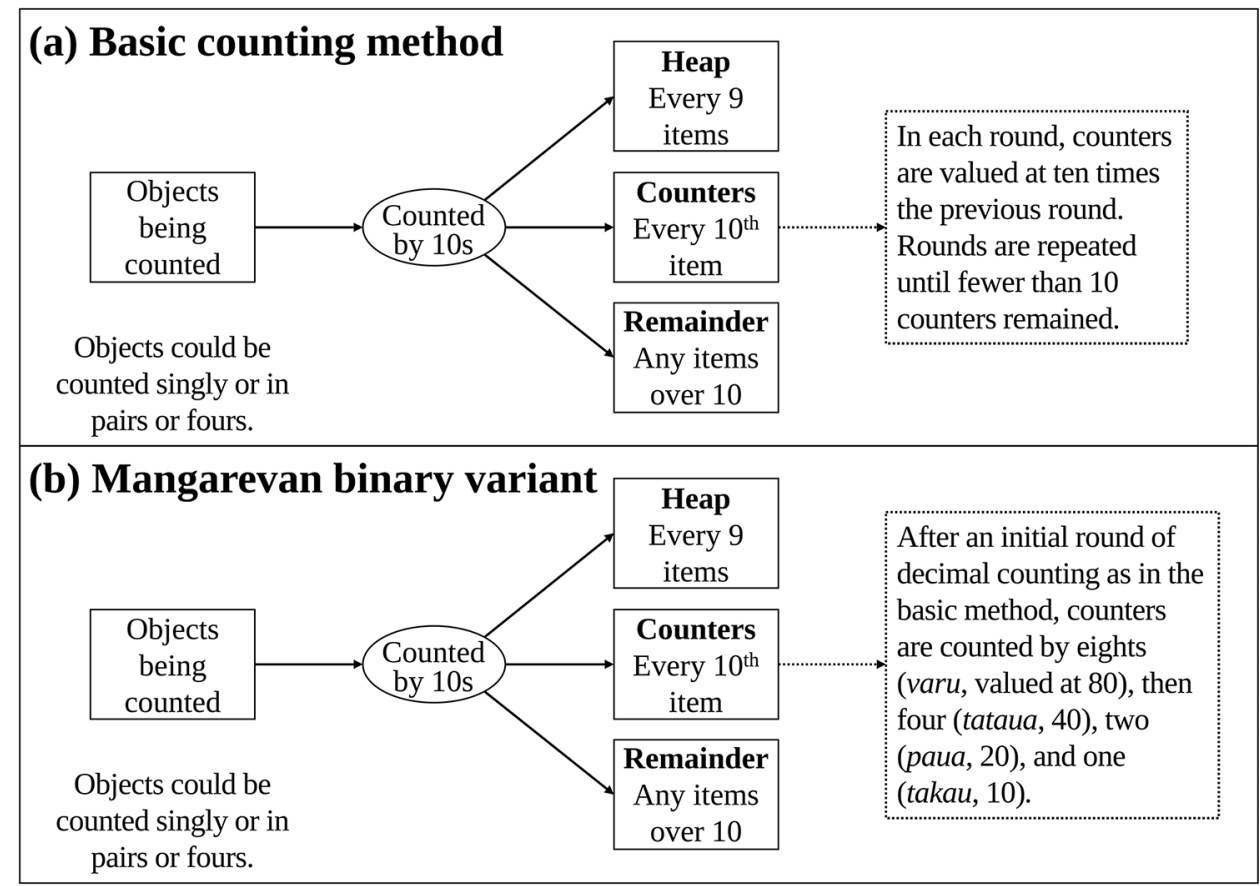

Figure 3-Traditional Polynesian Counting. (a) Basic counting method. This method of decimal counting produces the seemingly different results shown in Figure 2 because it works with singles, pairs, or fours as the basic unit. It works by setting aside every tenth item to represent ten items counted; the items set aside as counters acquire the value of 10 times the previous unit in the next round of counting. The method could be extended indefinitely, ending only when the number of counters dropped below ten. It explains why Polynesian counting could reach into the millions, was structured exponentially, and remained strongly decimal across time and distance despite the seeming absence of permanent devices for counting. (b) Mangarevan binary variant. In Mangareva, the counting method shown in (a) was adapted after an initial round of decimal counting to incorporate the binary relations between one, two, four, and eight. It too was capable of counting with singles, pairs, fours, or eights as the basic unit. Counting started as before, but in the second round, counting proceeded by eights, with any remaining counters counted by fours, then twos, and then one, producing one or none of these amounts. When added to the basic method, the Mangarevan variant produces the seemingly different results shown in Figure 4a (sequences 3-5) because both work with singles, pairs, fours, and eights. The diagrams were adapted from Overmann, "Curious Idea" (2020): 70-71, Figures 2 and 3. Readers interested in seeing the counting methods in operation, including the different outcomes yielded when the unit is adjusted between singles, pairs, fours, and eights, can consult an online algorithm provided for this purpose: https://doi.org/10.13140/RG.2.2.20943.71848/1.

where the unit following the hundreds was understood as tens rather than ones. ${ }^{86}$ This relative scale of values evokes the so-called floating sexagesimal place value of later Mesopotamian numbers, wherein exponential value was relative to the adjacent exponents and set by the context of use. ${ }^{87}$ Floating value can be difficult to understand from the perspective of an absolute scale, like Western numbers anchored by the decimal point, but may be intuitive in a system in which exponents take their value from their place within a counting sequence, as they did in traditional Polynesian counting.

As practiced in Polynesia, the method of counting was efficient and pragmatic. ${ }^{88}$ It minimized the physi-

\footnotetext{
${ }^{86}$ Best, "Māori Numeration" (1906): 179.

${ }^{87}$ Proust, "Du Calcul Flottant" (2013).

${ }^{88}$ Overmann, "Curious Idea" (2020): 69.
}

cal effort involved in counting bulky, heavy items like unhusked coconuts by (1) avoiding the need to create bundles of increasing size and weight, since sorting meant there was no need to create a thousand by grouping ten bundles of a hundred each; ${ }^{89}$ (2) handling most of the enumerated items only once; and (3) eliminating the need for ancillary recording, as the goods themselves served this purpose for the duration of counting. Similarly, the method minimized mental effort by (4) reducing counting to a matter of repetitively counting from one to $10^{90}$ and (5) using the goods themselves to keep track of the exponential

89 Ibid., "Counting by 'Elevens"” (2021): 17-19.

90 This remains implicit to Polynesian counting: "Typically, serial counting involves the numerals up to 10 and restarts from $1 \mathrm{ev}$ ery time a multiple of 10 is reached" (Bender and Beller, "Numeral Classifiers" [2006]: 387) 
register, with linguistic markers also helping to serve this purpose. Items (4) and (5) would have decreased demands on cognitive processes like memory and attention, while also increasing the likelihood that counting would produce accurate and reliable results. Counting collectively further reduced physical and mental effort ${ }^{91}$ by (6) condensing counting, by a factor of two when the unit was a pair (compare Figs. $2 \mathrm{~b}$ and $2 \mathrm{c}$ ), by four when the unit was a group of four, and in Mangareva, by eight when the unit was eight. ${ }^{92}$

In Mangareva, a unique variant emerged, ${ }^{93}$ facilitated by the availability of terms produced by counting with singles, pairs, fours, and eights and the binary relation between these values (see Fig. 3b). The variant began as usual, setting aside every tenth item to be used as a counter. However, in the second round, counting proceeded by eights (varu), giving the word varu two values within the same sequence, both eight and ten eights (this brings to mind the two different values the sign N46 has within the System $\breve{S}$ " for grain in the protocuneiform notations). Any remainder was then easily counted by fours (tatana), twos (pana), and ones (tanga). Binary counting was restricted to fairly low quantities, an upper limit ${ }^{94}$ that likely reflected the fact once counting proceeded by eights, it was no longer decimal. ${ }^{95}$

\section{Mental Calculation}

The claim that Polynesian numbers functioned as cognitively efficient tools for mental calculation requires some clarification. ${ }^{96}$ The intra- and inter-system relations that equivalued terms within and between the different counting sequences-a quality whose purported absence has been used as evidence of concreteness in the archaic Mesopotamian numbers-facilitated the mental performance of operations like doubling and exchanging, as these were implicit to expressing numerical values in language (e.g., as in the Hawaiian, Māori, and Tongan examples given). However, the idea of mental calculation goes further in assum-

\footnotetext{
${ }^{91}$ Bender and Beller, "Numeral Classifiers" (2007): 825.

${ }_{92}$ Handy, Native Culture (1923), 184; Janeau, Essai de Grammaire (1908), 20; Martin, Account of the Natives (1818), 370.

93 Overmann, "Curious Idea" (2020).

${ }^{94}$ Hiroa, Ethnology of Mangareva (1938), 417; Janeau, Essai de Grammaire (1908), 20.

95 Overmann, “Curious Idea” (2020): 78.

${ }^{96}$ Bender and Beller, "Counting in Tongan" (2007), "Extending the Limits" (2008), "Mangarevan Invention" (2014), "Numeration Systems" (2018), and “Power of 2" (2017).
}

ing that the redistribution of commodities, a common Polynesian social practice, necessarily involved arithmetic; that the absence of notations necessitated the arithmetic be performed mentally ${ }^{97}$; and that arithmetical calculations resembled those used in the West (e.g., "273 + 219)." 98 These assumptions are examined in turn, noting that even on a conservative interpretation, the claim that numbers were mentally manipulated is supported, and this in turn means that they were not concrete in the manner that has been supposed.

First, redistribution need not involve arithmeticnor numbers, for that matter-as societies with few numbers manage such things quite effectively (e.g., by pairing goods to ensure their equivalence). Along these lines, it must be noted that none of the dozens of Polynesian vocabularies, dictionaries, and grammars compiled by early explorers provide terms analogous to "addition" or "division," the operations most likely in accumulating goods given as tribute and distributing them between people. Similarly, where historical sources used terms like "reckoning," 99 they meant knowing the names of the higher exponents (e.g., million), not calculating per se. Nonetheless, the availability of highly elaborated numbers, plus their use in counting objects for social purposes of display, celebration, feasting, tribute, and gifting, suggests that Polynesian redistribution did involve, minimally, the kinds of calculations implicit to the linguistic expressions of numerical values.

Second, arithmetic need not have been performed mentally, as the physical arrangement of goods during counting meant they both represented the count in situ and were available to be manipulated in ways analogous to an abacus. Counting suggests the possibility that redistribution involved combining or separating goods and then recounting them, a material form of calculating. This would be consistent with historical accounts, which mention counting but not calculating per se. ${ }^{100}$ However, counting physical objects by the hundreds or thousands - let alone recounting them-is

\footnotetext{
97 Ibid., "Counting in Tongan" (2007): 228.

98 Ibid., "Mangarevan Invention" (2014): 1325.

99 Crook, Account of the Marquesas Islands (2007), 73.

${ }^{100}$ More recent descriptions must be viewed through the lens of Western cultural exposure and significant loss of traditional knowledge. A survey of dictionaries from the early nineteenth century shows that within decades of their introduction by missionaries, Western decimal numbers had largely replaced traditional ones, and several twentieth-century ethnographies mention informants having an imperfect grasp of traditional practices.
} 
laborious enough, even with efficient methods. Further, an abacus comprised of sizeable, weighty items like coconuts would not be ideal for complex manipulations. For these reasons, exponents like millions were unlikely to have represented physical counting. ${ }^{101}$ While this does not necessarily entail that the higher exponents were realized through calculating, they did reflect "a continuation of naming multiples," 102 a conceptual process in and of itself.

Finally, calculations need not have resembled Western ones, as the practice of rounding to the most significant digits was widespread. ${ }^{103}$ Rounding is documented by words that named the excess over a round number in counting (often glossed as remainder), including tūmā (common throughout Polynesia ${ }^{104}$ ), koena (Hawaiian ${ }^{105}$ ), akatouara (Mangarevan ${ }^{106}$ ), toēnga (Tuamotuan ${ }^{107}$ ), and tauwhara (Māori ${ }^{108}$ ). Rounding suggests the remainders produced by all but the final rounds of counting may simply have been labeled accordingly (see Figs. $3 \mathrm{a}$ and $3 \mathrm{~b}$ ), and that arithmetic, if used, might have been a relatively straightforward matter of combining the rounded significant units - of course, only if they all related to the same commodity. ${ }^{109}$ For example, adding 273 and 219 of sugarcane might have involved rounding both to two teau each. Given the same unit (teau), two tean and two tean of sugarcane would make four teau. With dissimilar units (teau and afe), two teau and two afe of sugarcane would make two afe and two teau (as ordered by magnitude). Arithmetic based on

${ }^{101}$ Bender and Beller, "Counting in Tongan" (2007): 232-33.

${ }^{102}$ Hiroa, Ethnology of Mangareva (1938), 417.

${ }^{103}$ Rounding down was implicit to counting as remainders discarded from all but the final rounds. Rounding up does not appear to have been used: "If eighty-three, or eighty-five, or eighty-six birds were put into a calabash [a gourd used as a utensil], that vessel would be said to contain hokowha (eighty), ka whakarerea nga tauwhara (the odd ones are omitted)" (Best, "Māori Numeration" [1906]: $155)$. If rounding up were practiced, quantities like 86 would be expected to occasion it.

${ }^{104}$ Lemaître, "Systèmes de Numération" (1985): 3.

105 Andrews, Vocabulary of Words (1836), 71.

106 Tregear, Dictionary of Mangareva (1899), 7.

107 Stimson, Dictionary of Some Tuamotuan Dialects (1964), 542 .

108 Best, "Māori Numeration" (1906): 166.

${ }^{109}$ Adding dissimilar commodities would likely have been difficult in both the Polynesian and Mesopotamian number systems since the same unit might not mean the same number of items; this in turn suggests a reason why the components yielding a sum might remain "identifiable" in Old Babylonian addition (Høyrup, Lengths, Widths, Surfaces [2002], 19). rounding would be consistent with intra- and intersystem relations, the exponential structure, the relative scale of value, and the kinds of operations implicit to linguistic expressions of numbers. Such arithmetic might differ from the Western variant in the details of its relations, operations, and algorithms, but its "mental" nature most certainly would not.

The interesting qualities of traditional Polynesian numbers - the multiple counting sequences with their specific patterns of composition, shared smallest unit, polyvalent and context-dependent value, and relative scale of value - can be traced to the method of counting. So too can aspects of expressing numbers in language, like the conjoined representation of quantity and commodity and the use of doubling and rounding. Without insight into the method of counting that explains and unites them, the various counting sequences create an impression of confusingly mixed bases and disconnected polyvalent terms, especially when the set of possible variants is incomplete. An example is shown in Figure 4a, the counting sequences of Mangareva. ${ }^{110}$ Omission of counting by fours or eights gives an impression of confused disconnectedness and mixed bases, though counting by fours was widespread in the eastern and northern peripheries, ${ }^{111}$ and counting by eights was documented in Mangareva. ${ }^{112}$ Even with those added, without the counting method, there is little basis for understanding how or even whether such counting sequences were related, leaving them as opaque to modern eyes as those of archaic Mesopotamia have been.

\section{Archaic Mesopotamian Number Systems, Reconsidered}

Mesopotamia, today roughly synonymous with the modern countries of Syria, Iran, and Iraq, was the ancient civilization that flourished in the region between the Tigris and Euphrates Rivers, famous as part of the fertile crescent where agriculture first developed (see Fig. 5). The region opened to human habitation during the climate shift that began the Holocene about 12,000 years ago. During the Neolithic (8300-4500 BC), extant populations from the Levant and Zagros Mountains

\footnotetext{
${ }^{110}$ As recorded by Hiroa (Ethnology of Mangareva [1938], 417) and as visualized after Nissen, Damerow, and Englund (Archaic Bookkeeping [1993], 28-29, Figure 28).

111 Overmann, “Curious Idea" (2020): 72, Figure 4.

112 Janeau, Essai de Grammaire (1908), 20.
} 
a

\begin{tabular}{|c|c|c|c|c|c|c|c|c|c|}
\hline \multirow{2}{*}{$\begin{array}{l}\text { (1) General } \\
\text { (counting by } \\
\text { sorting with singles }\end{array}$} & makiukiul ${ }^{10}$ & makiu & mano & 10 & rau & 10 & takau & 10 & item \\
\hline & s) 100,000 & 10,000 & 1000 & & 100 & & 10 & & 1 \\
\hline (2) Breadfruit & makiu $: 10$ & \begin{tabular}{|l|}
$\operatorname{mano}$ \\
\end{tabular} & rau & 10 & takau & 10 & unit & 2 & item \\
\hline $\begin{array}{l}\text { (counting by } \\
\text { sorting with pairs) }\end{array}$ & 20,000 & 2000 & 200 & & 20 & & 2 & & 1 \\
\hline (3) Turtles & & varu & tataua & 2 & paua & & takau & 10 & item \\
\hline $\begin{array}{l}\text { (binary counting } \\
\text { with singles) }\end{array}$ & & 80 & 40 & & 20 & & 10 & & 1 \\
\hline (4) Fish & varu & tataua $:^{2}$ & paua & 2 & takau & 10 & unit & 2 & item \\
\hline $\begin{array}{l}\text { (binary counting } \\
\text { with pairs) }\end{array}$ & 160 & 80 & 40 & & 20 & & 2 & & 1 \\
\hline (5) Coconuts & varu & \begin{tabular}{|l|} 
tataua \\
2
\end{tabular} & paua & 2 & takau & 10 & unit & 4 & item \\
\hline $\begin{array}{l}\text { (binary counting } \\
\text { with fours) }\end{array}$ & 320 & 160 & 80 & & 40 & & 4 & & 1 \\
\hline
\end{tabular}

b

\begin{tabular}{|c|c|c|c|c|c|c|c|c|c|c|c|}
\hline $\begin{array}{l}\text { (1) General } \\
\text { (counting by } \\
\text { sorting with singles) }\end{array}$ & $\underset{100,000}{0}$ & 10 & ${ }_{10,000}$ & $\stackrel{10}{\longleftarrow}$ & $\begin{array}{r}10 \\
1000\end{array}$ & 10 & $\sum_{100}^{D}$ & $\stackrel{10}{\longleftarrow}$ & $\stackrel{\bullet}{10}$ & $\stackrel{10}{\longleftarrow}$ & $\begin{array}{c}b \\
1\end{array}$ \\
\hline (2) Breadfruit & 0 & $\stackrel{10}{\longleftarrow}$ & 10 & $\stackrel{10}{\longleftarrow}$ & $D$ & 10 & $\bullet$ & $\stackrel{10}{\longleftarrow}$ & $\infty$ & 2 & 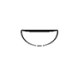 \\
\hline $\begin{array}{l}\text { (counting by } \\
\text { sorting with pairs) }\end{array}$ & 20,000 & & 2000 & & 200 & & 20 & & 2 & & 1 \\
\hline (3) Turtles & & & $D$ & 2 & O & 2 & 0 & $\stackrel{2}{\longleftarrow}$ & - & $\stackrel{10}{\longleftarrow}$ & 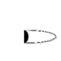 \\
\hline $\begin{array}{l}\text { (binary counting } \\
\text { with singles) }\end{array}$ & & & 80 & & 40 & & 20 & & 10 & & 1 \\
\hline (4) Fish & $D$ & 2 & 0 & 2 & 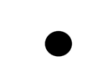 & 2 & $\bullet$ & 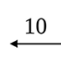 & $D$ & 2 & $\triangleright$ \\
\hline $\begin{array}{l}\text { (binary counting } \\
\text { with pairs) }\end{array}$ & 160 & & 80 & & 40 & & 20 & & 2 & & 1 \\
\hline (5) Coconuts & 1 & $\stackrel{2}{\longleftarrow}$ & O & 2 & 0 & 2 & $\bullet$ & $\stackrel{10}{\longleftarrow}$ & $D$ & 4 & $\varepsilon$ \\
\hline $\begin{array}{l}\text { (binary counting } \\
\text { with fours) }\end{array}$ & 320 & & 160 & & 80 & & 40 & & 4 & & 1 \\
\hline
\end{tabular}

Figure 4a-b-Counting in Mangareva. (a) Five Mangarevan counting sequences as recorded by Hiroa (Ethnology of Mangareva [1938], 417) and as visualized after Nissen, Damerow, and Englund (Archaic Bookkeeping [1993], 28-29, Figure 28). The first two (general and breadfruit) used the counting method shown in Figure 3a, the last three (turtles, fish, and coconuts) the counting method shown in Figure $3 \mathrm{~b}$. Without insight into the counting method, these counting sequences and their polyvalent terms might remain oddly disconnected, as they have been in the Mesopotamian number systems. Comparing these sequences to those in Figure 3 also highlights the importance of visualization in interpreting numerical structure and organization. (b) Hypothetical replacement of the counting sequences in Figure 4a with token shapes; the result resembles the proto-cuneiform counting sequences of the Uruk period in Mesopotamia. Note that relative to counting with singles (sequences 1 and 3), counting with pairs (sequences 2 and 4 ) and fours (sequence 5) displaces the unit upward (i.e., one place to the left, a higher numerical magnitude).

expanded into the Mesopotamian plain. ${ }^{113}$ Today these groups are known as Akkadians, Elamites, and Sumerians, names more convenient as modern labels than

$$
{ }^{113} \text { Lazaridis, et al., "Genomic Insights.” }
$$

accurate as reflections of ancient social, ethnic, and cultural identities. The Neolithic was associated with rapid demographic increase, larger and more permanent settlements, and impressive innovation. The latter included one of the earliest known systems of writing 


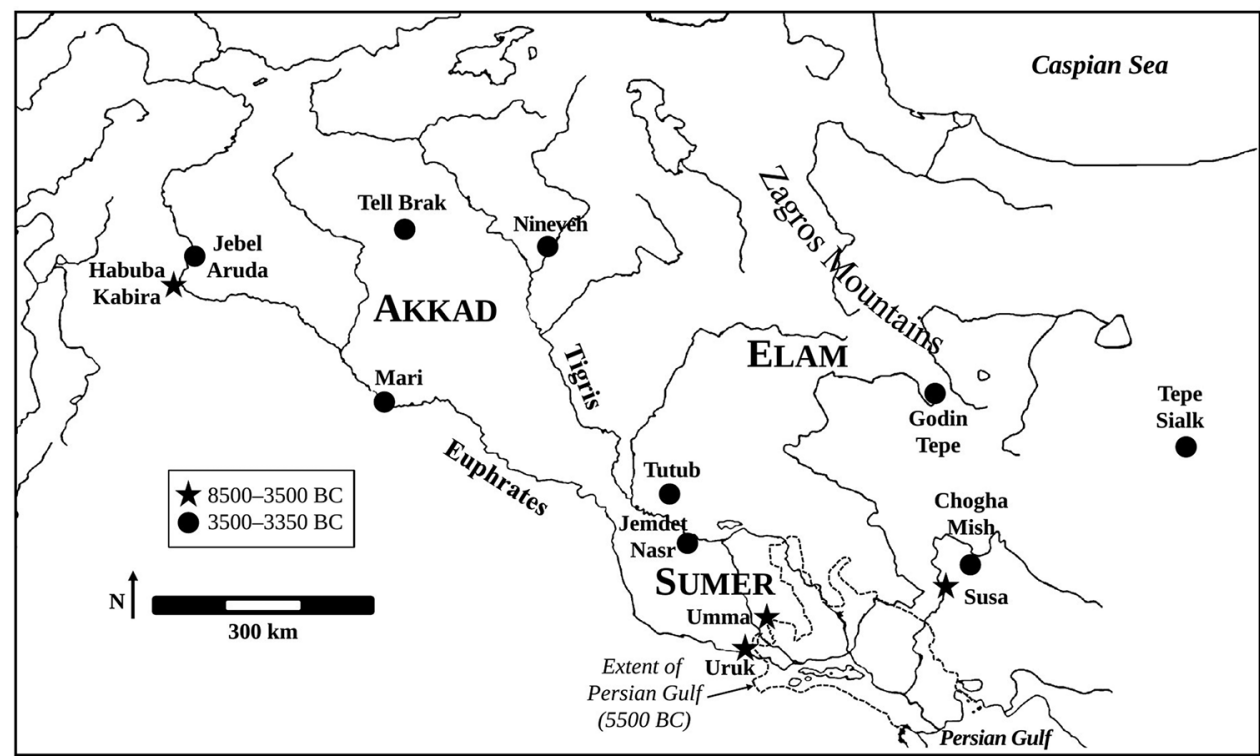

Figure 5-Mesopotamia in the third millennium BC, with the geographic locations of three major linguistic groups: Sumer, Akkad, and Elam. Sumer was located to the west of the top of the Persian Gulf, which at the time extended inland much further than it does today (as represented by the dashed lines), an area that today is roughly contiguous with Iraq. Akkad lay further west and to the north of Sumer in what is now Syria, Elam to the east and north in modern-day Iran. Even during the earliest period (Pre-Uruk V, 8500-3500 BC), token and impression assemblages were widely distributed throughout the region, either through trade (e.g., Susa in Elam) or as cultural outposts (e.g., Habuba Kabira, an Uruk settlement in Akkad). The map was adapted from an image in the public domain; data were sourced from Overmann, Material Origin (2019); Schmandt-Besserat, Before Writing vol. 2 (1992).

and numbers, which would become elaborated as literacy and mathematics by the Old Babylonian period $\left(2000-1600\right.$ вС). ${ }^{114}$

\section{Characteristics of Mesopotamian Numbers}

The numerical traditions associated with the Sumerians, Akkadians, and Elamites were distinctive. As attested by the notations used, the first was sexagesimal in structure, the others decimal. Numbers differed linguistically as well, as is clear from the phonetic values for numberwords that emerged in writing in the mid-third millennium BC. These show the Sumerians to have had a "quinary-vigesimal system, with traces of decimal counting" 115 at quantities below sixty, the point at which numbers became sexagesimal. ${ }^{116}$ Akkadian spoken numbers were decimal, as is typical for Semitic languages. ${ }^{117}$

114 Overmann, Material Origin (2019); Robson, "Mesopotamian Mathematics" (2007); Veldhuis, "Levels of Literacy" (2011).

115 Seidenberg, "Sixty System of Sumer" (1965): 440.

${ }^{116}$ Blažek, Numerals (1999), 329; Powell, "Origin of the Sexagesimal System" (1972): 7.

${ }^{117}$ Huehnergard, "Proto-Semitic" (2019); Lipínski, Semitic Languages (2001); Miller and Shipp, Akkadian Handbook (2014); Powell, "Notes on Akkadian Numbers" (1979).
Elamite spoken numbers likely differed from both, given their decimal adaptation of the sexagesimal notations ${ }^{118}$ and Elamite's status as a linguistic isolate, but as these numbers are known only as numerical notations, their sound values are unknown. ${ }^{119}$ All three languages also differed in grammatical number, the feature of language that distinguishes singular from plural, in terms of its structure, method of marking, and animacy. ${ }^{120}$

As neighboring number systems tend toward similarity of structure, organization, and extent, ${ }^{121}$ the substantial differences between notational and spoken forms of numbers suggest the three numerical traditions originated independently ${ }^{122}$ - that is, before the societies

\footnotetext{
118 Englund, "State of Decipherment" (2004), 107-108, 110-13.

119 Tavernier, "Elamite" (2020), 175-76.

${ }^{120}$ Overmann, Material Origin (2019), 121-23.

${ }^{121}$ Overmann, "Material Scaffolds" (2013): 23-26.

${ }^{122}$ Neither lexical numbers nor grammatical number appeared
} in writing for centuries after writing was invented. Consistent with the view of Neolithic numbers as severely concrete, this has sometimes been interpreted to mean ancient languages may have lacked these features (Dahl, "Comment on 'Numerosity'" [2015]: 647-48), though this seems unlikely, given that tokens, impressions, and notations had numerical meaning. A more likely explanation for the relatively late emergence of numerical features in writing is found in the combination of two circumstances. First, early writing 
came into the increased contact with one another that characterized the Neolithic. In fact, small numberwords have been reconstructed for Proto-Afroasiatic, the hypothetical reconstructed language ancestral to Proto-Semitic (and thus, Akkadian) spoken in the Levant before the Neolithic. ${ }^{123}$ Worked bones with possible utility as tallies dated to the Late Upper Paleolithic have also been found in the Levant. ${ }^{124}$ These suggest that spoken and material forms of numbers were not only available before the Neolithic but may have had a lengthy prehistory prior to their representation by tokens. $^{125}$

The technologies used to represent and manipulate numerical information-tokens, numerical impressions, proto-cuneiform notations, and cuneiform numbershave been connected through correspondences of shape, size, and quantity, with their meaning anchored by the unambiguously numerical nature of cuneiform numbers. ${ }^{126}$ Though these technologies were shared between the various societies and cultures that comprised

lacked the ability to represent sound values, techniques that began to appear in the third millennium BC (Hyman, "Of Glyphs and Glottography" [2006]). Second, written numbers are semantically meaningful without phonography and in fact lose essential qualities and capabilities through the visual complexity it adds (e.g., contrast the concision and ability to represent numerical and spatial relations of 23,115 and twenty-three thousand, one hundred and fifteen). This meant there had to be reasons to add sound values to numbers. And indeed, Akkadian scribes wrote hundred and thousand phonetically because these decimal terms lacked concise sexagesimal counterparts (Thureau-Dangin, "Sketch of a History" [1939]: 107), and as Sumerian became a classical language (Woods, "Bilingualism" [2006]), Akkadian scribes recorded the sound values of small numbers (e.g., two through ten; see Edzard, "Sumerisch 1 bis 10 in Ebla" [1980]), much as someone today might be motivated to learn Latin names for Roman numerals.

${ }^{123}$ Blažek, "Afroasiatic Migrations" (n.d.); Ehret, Reconstructing Proto-Afroasiatic (1995).

${ }^{124}$ Overmann, Material Origin (2019), 146-52. While the Paleolithic/early Neolithic artifacts are ambiguous regarding any use as tallies, they would have provided "the kind of tactile and visual regularity important in numerical patterning" (ibid., "Role of Materiality" [2016]: 48); textual sources mention tallies in the third millennium (Black et al., Electronic Text Corpus, "Debate between Grain and Sheep" [2005]: c.5.3.2), unambiguous artifactual tallies appear in the first millennium (Henkelman and Folmer, "Your Tally Is Full!" [2016]).

125 Overmann, Material Origin (2019), 127-30. Proto-numbers cannot be reconstructed for Sumerian or Elamite, as both are isolates.

${ }^{126}$ Amiet, MDP 43 vol. 1 (1972), 67-108; Englund, "Examination of the "Textual' Witnesses" (2006), "State of Decipherment" (2004), and "Texts from the Late Uruk Period" (1998); Friberg, "Preliterate Counting" (1994); Nissen, Damerow, and Englund, Archaic Bookkeeping (1993).
Mesopotamia, the invention of sexagesimal numeration is usually ascribed to the Sumerians, ${ }^{127}$ an origin warranted by the strong and persistent decimality of Akkadian numbers in particular. Together, these technologies were used over a period of several thousand years. This temporal span remains impressive even when tokens are considered only from the mid-fourth to the late third/early second millennia $\mathrm{BC}$, or from the point at which associated impressions corroborate their numerical meaning to the point at which their archaeological prevalence significantly dwindles, as perhaps replaced by a form of abacus. ${ }^{128}$ While the four technologies are archaeologically and textually attested as emerging in the sequence given, ${ }^{129}$ concurrent use was significant, with tokens persisting as a manipulable technology suitable for calculating. ${ }^{130}$ This was unlike numerical impressions, proto-cuneiform notations, and cuneiform numbers, which were effectively fixed once they had been impressed into clay.

\section{Mesopotamian Accounting}

As represented by tokens, numerical impressions, and proto-cuneiform notations, archaic Sumerian numbers consisted of a general system and over a dozen specialized systems for counting specific items (see Fig. 6). ${ }^{131}$ Tokens, the earliest of these numerical technologies, are understood as numerical counters when

127 Powell, "Sumerian Area Measures" (1972): 172, claimed that "the presence of a sexagesimal system of notation in the archaic texts from Uruk and Jemdet Nasr constitute[s] the best-indeed irrefutable-evidence that Sumerian is the language of those texts."

128 Tokens may have been replaced by undifferentiated counters valued solely by their physical placement on a counting surface (Woods, "Abacus in Mesopotamia" [2017]), plausibly in conjunction with the emergence of other simplified/standardized forms (e.g., cuneiform numerals and place value) in the late third/early second millennium BC (Chrisomalis, Numerical Notation [2010], 243; Robson, Mathematics in Ancient Iraq [2008], 16, 75-76). For an analysis of archaeological prevalence, see Overmann, Material Origin (2019), 172-73.

129 The sequence of counting technologies that are the focus here consisted of tokens used as numerical counters (prior to $3500 \mathrm{BC}$ ), envelopes containing tokens (3500-3400 BC), numerical impressions that resembled tokens (3400-3350 BC), and proto-cuneiform notations (3300 BC and thereafter) (Englund, "State of Decipherment" [2004], 122, Figure 5.12). Notably, none provides insight into spoken numbers.

${ }^{130}$ Høyrup, Lengths, Widths, Surfaces (2002), 73, 195-96; Overmann, Material Origin (2019), 170-73, 198-99.

${ }^{131}$ Nissen, Damerow, and Englund, Archaic Bookkeeping (1993), 28-29, Figure 28. 


\begin{tabular}{|c|c|c|c|}
\hline Integers & Unit & $\mathrm{Fr}$ & \\
\hline 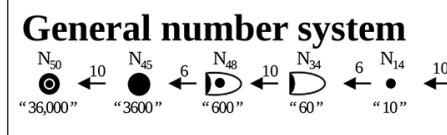 & $\begin{array}{l}N_{1} \\
c_{1} \\
C_{10}\end{array}$ & 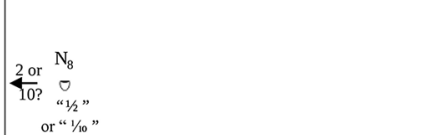 & S: Most objects \\
\hline Specialized number systen & 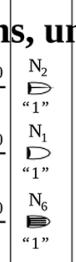 & 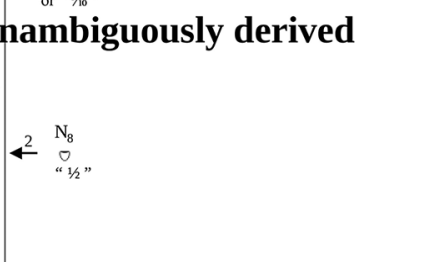 & $\begin{array}{l}S^{\prime} \text { : Certain objects } \\
B: \text { Food rations } \\
B^{*} \text { : Certain rations }\end{array}$ \\
\hline \begin{tabular}{cccc} 
Specialized number systen \\
\hdashline
\end{tabular} & 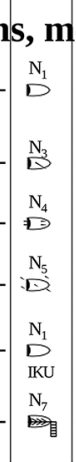 & 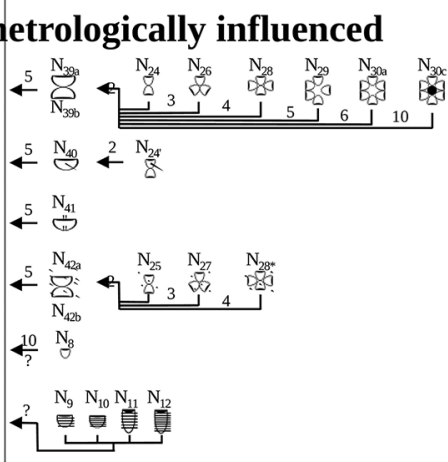 & $\begin{array}{l}\check{S}: \text { Grain (barley) } \\
\breve{S}^{\prime} \text { : Grain (malt) } \\
\check{S}^{\prime \prime} \text { : Grain (emmer) } \\
\check{S}^{*} \text { : Grain (groats) } \\
\text { G: Area calculations } \\
\begin{array}{l}\text { E: Weight measure } \\
\text { (Uruk IV period) }\end{array}\end{array}$ \\
\hline
\end{tabular}

Figure 6-Proto-cuneiform Counting Sequences. Mesopotamian general and derived counting sequences. The derived sequences were categorized by how closely they conformed to the general sequence. Unambiguously derived sequences counted discrete objects capable of being bundled or counted individually. These sequences were differentiated by what they counted (Purpose column) and the extent of counting; Systems B and B* were further differentiated by the addition of a binary step after sixty that shifted subsequent values upward by a factor of two. Metrologically influenced sequences varied more extensively (also see Table 3). These systems involved containers for bulk items like grain or oil or continuous extents like area. These sequences reversed the initial bundling of the general sequence, with the next highest value above the unit worth six instead of ten. Possibly this reflected an aspect of the counting method, with fractional units perhaps combining to a unit that would shift subsequent values to the expected patterning of ten and six (as would be consistent with Figure 4b). Source: redrawn from Nissen, Damerow, and Englund (Archaic Bookkeeping [1993], 28-29, Figure 28) and aligned according to Damerow and Englund (ATU 2 [1987], 165). Consistent with ATU2, the specialized sequences for time (U) and dairy products (Db and Dc) are not shown; they would be categorized as metrologically influenced.

accompanied by corresponding numerical impressions. As listed in the Cuneiform Digital Library, the signs in token-impression assemblages assigned to the PreUruk V period (8500-3500 BC) are consistent with the general sexagesimal counting sequence $(S)$, bisexagesimal counting (B), and the systems for area (G) and capacities of grain $\left(\breve{S}, \breve{S}^{\prime}\right.$, and $\left.\breve{S}^{\prime \prime}\right)$. These assemblages were distributed throughout the region, representing trade and cultural outposts (see Fig. 5). As was true of Polynesia, specified counting appears to have been used with commodities "important enough to be counted with more than sporadic frequency, and at the same time ... sufficiently abundant to make an abbreviation [of the counting process] desirable." ${ }^{32}$

In comparison to the token-impression assemblages, proto-cuneiform notations (Uruk V [3500-3350 BC] and thereafter) provide insight into an expanded set of

\footnotetext{
${ }^{132}$ Beller and Bender, "Cognitive Advantages” (2005): 218.
}

specialized number systems, and accordingly, are used here as providing the most detailed insight for the comparison with Polynesian counting sequences. As shown by the proto-cuneiform notations, the general number system had a regular sexagesimal structure comprised of an alternating sub-base of ten and base of $s i x,{ }^{133}$ with signs within each system related through bundling (e.g., ten $\mathrm{Nl}$ were equivalent to one N14; six N14 to one N34; etc.; see Fig. 6). The specialized systems were likewise sexagesimal but can be categorized according

${ }^{133}$ Thureau-Dangin, "Sketch of a History" (1939): 102-105. The base of a number system is the value used to produce other numbers (Comrie, "Numeral Bases" [2013]). For example, in decimal, the number ten is the base, and ten and its multiples (bundred, thousand, etc.) are productive. Some number systems also have sub-bases, a smaller value with the same productive function. While Western decimal numbers lack a sub-base, Roman numerals had a sub-base of five, adding V, L, and D $(5,50$, and 500) to the decimal powers of ten (X, C, and M, or 10, 100, and 1000). 
Table 3-Characteristics of Uruk-period Specialized, Derived Number Systems. Six traits of the Uruk-period specialized, derived number systems were compared to those of the general system, Sexagesimal System S. As can be seen, unambiguously derived systems conformed more closely to the general system, while the metrologically influenced systems were more likely to contain polyvalent, context-dependent values. Dashes indicate that a counting sequence lacked the information needed for comparison.

\begin{tabular}{|c|c|c|c|c|c|c|c|c|c|}
\hline \multirow{3}{*}{$\begin{array}{l}\text { System traits (compared to those } \\
\text { of the general system, System S) }\end{array}$} & \multicolumn{9}{|c|}{ Derived systems } \\
\hline & \multicolumn{3}{|c|}{ Unambiguous } & \multicolumn{6}{|c|}{ Metrological } \\
\hline & $S^{\prime}$ & B & $\mathrm{B}^{*}$ & $\stackrel{\vee}{S}$ & $\stackrel{\vee}{S}^{\prime}$ & $\stackrel{\vee}{S} "^{\prime \prime}$ & $\stackrel{\vee}{S} *$ & $\mathrm{E}$ & G \\
\hline Lowest unit sign is shared & Yes & Yes & Yes & Yes & Yes & Yes & Yes & Yes & Yes \\
\hline Lowest unit value is shared & Yes & Yes & Yes & No & No & No & No & Yes & No \\
\hline $10-6$ patterning is shared & Yes & Yes & Yes & No & No & No & No & - & No \\
\hline New bundling values introduced & - & Yes & Yes & Yes & - & Yes & Yes & - & Yes \\
\hline Polyvalent value & No & Yes & No & Yes & Yes & Yes & No & Yes & Yes \\
\hline Bundling multiplication is regular & - & Yes & Yes & No & - & No & No & - & No \\
\hline
\end{tabular}

to how closely their composition followed the general pattern (see Table 3). Systems in the first category were unambiguously derived from the general system, following it in structure, organization, and bundling and deviating from it in regularized ways (e.g., both bisexagesimal systems included a binary step after sixty that shifted subsequent values upward by a factor of two). Systems in the second category conformed less to the general system. They were used with commodities counted in bulk like grain and the continuous extents of area, so their bundling may have influenced by metrological relations and considerations. Alternatively, they might indicate adaptations of the counting method, analogous to the binary variant of Polynesian counting found in Mangareva (see Fig. 3b).

Like the Polynesian counting sequences, protocuneiform number systems shared their lowest unit: this was the sign $\mathrm{Nl}$ and its variants made by adding marks like horizontal lines. These number systems also comprised relative scales of value, to the extent that numerical values cannot always be assigned to them with certainty. ${ }^{134}$ These number systems included polyvalent, contextually dependent terms, as for example, $\mathrm{N} 45$ meant 3,600 or had a relative value of ten N14 or six N50, depending on whether it appeared in Sys-

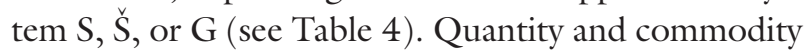
were conjointly represented: the former as repetition, the latter as shape and size, and both with reference to which signs were present and how they were ordered. While this quality has been used to characterize ancient numbers as concrete when representation was conjoined (tokens and impressions) and abstract when it was separated (proto-cuneiform notations and

${ }^{134}$ Nissen, Damerow, and Englund, Archaic Bookkeeping (1993). cuneiform numbers), ${ }^{135}$ the Polynesian data suggest that, alternatively, conjoined quantity and commodity may have reflected the linguistic differentiation of object-specific counting and/or numeral classifiers. It is possible that Sumerian number-words were similarly differentiated at one time, a feature perhaps lost by the time the sound values of number-words were recorded in writing.

\section{Mental Calculation}

Overall, their parallels with Polynesian numbers suggest that the archaic Mesopotamian number systems might well have gained their interesting qualities from a method of counting that differed according to the commodity being counted. Such an origin would suggest that the ancient numbers possessed not just the intra-system (bundling) relations shown in the numerical impressions and early proto-cuneiform notations, but inter-system relations as well, with polyvalent terms likely differentiated linguistically in a way that tokens and notations cannot show because they lack a phonetic component. An origin in counting would also suggest that the archaic Mesopotamian numbers were likely to have been, as Polynesian numbers were, cognitively efficient tools for mental calculation. Here the sexagesimal factorability was likely to have been advantageous. However, Sumerian number-words below sixty

135 E.g., Damerow, Abstraction and Representation (2010), 15966, 275-97, “Individual Development” (1988): 133-51, "Number as a Second-Order Concept" (1996), and "Prehistory and Cognitive Development" (1996); Schmandt-Besserat, Before Writing Vol. 1 (1992), "Emergence of Recording" (1982), "From Tokens to Tablets" (1981), "Prehistoric Administrative Technologies" (2018), and “Token System" (2010). 
Table 4-Shared and Polyvalent Signs in the Proto-cuneiform Number Systems. Signs were shared by different counting sequences with either the same or different value, making the latter polyvalent and context dependent. That is, some shared signs may have had the same value regardless of the counting sequence in which they appeared (e.g., Nl, unit), while others acquired a value particular to the sequence in which it was used (e.g., Nl4 was worth ten of the unit in Systems S, B, and E but six of the unit in Systems $\breve{S}$ and G). N46 was unique in having two different values within a single counting sequence $(\breve{S} ")$, differentiated by position of use; this evokes the term varu in Mangarevan binary counting, which has the value eight when positioned lower in the sequence and ten eights in the higher position.

\begin{tabular}{lll}
\hline \hline Sign & \multicolumn{1}{c}{ Systems } & \multicolumn{1}{c}{ Remark } \\
\hline $\mathrm{N}_{1}$ & $\mathrm{~S}, \breve{S}, \mathrm{E}, \mathrm{G}$ & Shared; same value \\
$\mathrm{N}_{2}$ & $\mathrm{~S}$ ', B & Shared; same value \\
$\mathrm{N}_{8}$ & $\mathrm{~S}, \mathrm{~B}, \mathrm{E}, \mathrm{G}$ & Polyvalent, context-dependent value \\
$\mathrm{N}_{14}$ & $\mathrm{~S}, \mathrm{~B}, \breve{S}, \mathrm{E}, \mathrm{G}$ & Polyvalent, context-dependent value \\
$\mathrm{N}_{24}$ & $\breve{S}^{\prime}, \mathrm{E}$ & Polyvalent, context-dependent value \\
$\mathrm{N}_{34}$ & $\mathrm{~S}, \mathrm{~B}, \check{\mathrm{S}}$ & Polyvalent, context-dependent value \\
$\mathrm{N}_{45}$ & $\mathrm{~S}, \breve{S}, \mathrm{G}$ & Polyvalent, context-dependent value \\
$\mathrm{N}_{46}$ & $\mathrm{~S}^{\prime \prime}$ & Polyvalent; two values within the same \\
$\mathrm{N}_{48}$ & $\mathrm{~S}, \check{S}$ & system \\
$\mathrm{N}_{50}$ & $\mathrm{~S}, \mathrm{G}$ & Polyvalent, context-dependent value \\
$\mathrm{N}_{54}$ & $\mathrm{~B}, \mathrm{~B}$ * & Polyvalent, context-dependent value \\
\hline & & Shared; same value \\
\hline
\end{tabular}

were quinary-decimal-vigesimal in structure. ${ }^{136}$ As a result, sexagesimal factorability may have been used to express numbers higher than sixty, with numbers lower than sixty expressed decimally, analogous to way Hawaiian numbers were traditionally expressed (see Table 1 ). This possibility might then position the step above sixty - doubled in Systems B and B* and tripled in Systems $\check{S}, \breve{S}^{\prime \prime}$, and $\check{S}^{*}$-as a feature marking the shift between the two. It also implies that sexagesimal factorability might not have been as pervasive as binary factorability was to Polynesian numbers, particularly in numbers lower than sixty, leaving the nature of the corresponding mental calculations less clear.

There were also significant differences between the two. For example, the archaic Mesopotamian number systems are less clearly derived from a single method of counting in the way demonstrable for Polynesia. While it is possible to construct a sexagesimal variant

${ }^{136}$ Blažek, Numerals (1999), 329; Powell, "Origin of the Sexagesimal System" (1972): 7. Sumerian number-words below sixty were organized by five, ten, and twenty: Six is glossed as $5+1$; seven, $5+2$; nine, $5+4$; thirty, $3 \times 10$; forty, $20 \times 2$; and fifty, $40+10$. Structuring by five and ten emerges from counting with the hands, twenty from recruiting the feet (Epps, et al., "On Numeral Complexity" [2012]: 67), typically producing decimal or quinaryvigesimal number systems. of the Polynesian counting method, the result neither unifies nor explains all the specialized systems found in the proto-cuneiform notations, particularly the ones influenced by metrology. A single counting method would also not explain why the metrologically influenced systems reversed the ten-six bundling of the general number system. It is possible that fractional units were combined into a unit in a way analogous to counting with pairs or fours. This would shift some of the subsequent values to the expected ten-six patterning, and it would also offset the associated signs from those of the general system (as is true in the hypothetical replacement of Polynesian units by token-like shapes; see Fig. 4b, sequences 2, 4, and 5 ). In addition, archaic Mesopotamian exponential structure did not exhibit the same extensibility as Polynesian counting, which may have reached $10^{8}$ in Mangareva in eastern Polynesia and $10^{10}$ in Nukuoro, a Polynesian outlier in Micronesia. ${ }^{137}$ Instead, it appears to have expanded more slowly, perhaps as occasioned by the competitive boasting of kings. ${ }^{138}$ However, it may also be the case that there are currently insufficient data from which to reconstruct a unifying counting method for Mesopotamia, one that can account for both the metrological variants and things like the dual use of signs for quantity (e.g., N46 in System Š" for grain).

\section{The Material Difference}

Crucially, archaic Mesopotamian counting differed in its material substrate. Where the enumerated goods themselves were used as counters in Polynesia, small objects made of clay (tokens) or impressions and notations made on clay surfaces (writing and its impressed precursors) were used in Mesopotamia. Obviously, if

${ }^{137}$ Harrison and Jackson ("Higher Numerals" [1984]: 61) noted a Nukuoro term for $10^{10}$ but did not specify what it was. Lemaittre ("Systèmes de Numération" [1985]: 9, Table 5) gave maeaea as the Mangarevan term for $10^{8}$, though Hiroa (Ethnology of Mangareva [1938], 417) valued it as $10^{7}$. The exponential reach of both is consistent with the Proto-Polynesian (PPn) term for $10^{6}$, *ki(l)u, given by Clark ("Proto-Polynesian Numerals" [1999]: 197). Clark also questioned the PPn term, not because of its cognate status or geographic distribution, but rather, on grounds of doubting "whether anyone in [Proto-Polynesian] times ever had a million of anything, or even counted that high as a mental exercise" (Ibid.). See Bender and Beller, “Fanciful' or Genuine?” (2006): 38-41 and "Numeral Classifiers" (2006): 400-401 for reasons why such terms should be accepted.

${ }^{138}$ Howorth, "Later Rulers" (1902): 14; Thureau-Dangin, "Nouveau Cône" (1900): 383-84. 
material forms had not been used to represent numbers, this ancient numeracy would have remained invisible, beyond its influence on descendent number systems. But the significance of tokens and notations exceeds this, as they enabled numbers to be separated from the process of counting. ${ }^{139}$ Separating numbers from the items they counted by means of material proxies was at least as significant as separating the representation of quantity and commodity, for it helped influence numbers toward being conceived as objects more defined by their relations to one another than the things they enumerated, influencing numbers toward becoming a relational system.

Using these material forms as proxies also afforded opportunities for their material properties, relations, and capabilities to inform numerical ones. ${ }^{140}$ For example, the manipulability of tokens (and later abacus counters $^{141}$ ) not only enabled the explication of relations and performance of calculations, but also influenced the conceptualization of numbers as objects which could be manipulated, even when represented by fixed notations. Notational concision made feasible the accumulation of relational data at volumes well beyond those possible with tokens. This would have influenced numbers toward being conceived in relational terms, and calculation toward the increased involvement of relational data as an alternative to manipulating counters. Concision also increased the volume of data that could be visually appreciated at one time, increasing the potential for recognizing numerical patterns and relations. And the combined use of tokens for calculating and notations for recording enabled bundling/debundling operations and calculations to become much more complex than the limits of human memory could afford.

Writing too would significantly affect how numbers were conceived. Handwriting would occasion the neurological reorganization that enables characters to be recognized through their features and context rather than their resemblance to objects. ${ }^{142}$ As this phenom-

${ }^{139}$ Malafouris, "Grasping the Concept" (2010) and How Things Shape the Mind (2013), 106-16.

${ }^{140}$ Frege, Foundations of Arithmetic (1953), xv-xvi, 22; Hutchins, "Material Anchors" (2005): 1562; also see discussion in Overmann, Material Origin (2019), 36-40, 179-227.

${ }^{141}$ E.g., undifferentiated counters as used with an abacus (Woods, "Abacus in Mesopotamia" [2017]).

${ }^{142}$ Coltheart, "Neuronal Recycling Hypothesis" (2014); Dehaene and Cohen, "Cultural Recycling" (2007); Dehaene, et al., "Illiterate to Literate" (2015). enon transformed early writing into a system of literacy, ${ }^{143}$ it also helped influence numbers toward being conceived as entities (as represented and influenced by single signs) rather than collections of objects (sets of tokens), even though both are composed of mul-

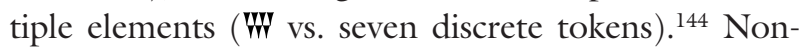
numerical writing also allowed calculations to be documented, codified, and elaborated, allowing them to be analyzed and influencing them toward greater complexity. And as calculations were becoming more complex, they were also becoming more dependent on both the mental knowledge of numerical relations and the use of material forms to record results and visualize patterns.

The comparison with traditional Polynesian counting has yielded a radically different interpretation for archaic Mesopotamian numbers. The Polynesian data suggest that multiple counting sequences, specific compositional patterns, a shared term for a smallest unit with variable numerical value, polyvalent terms with contextual value, conjoined representation of quantity and commodity, and relative scales of value might not be, after all, characteristic of non-abstract, rudimentary concepts of numbers used in strict one-to-one correspondence in the manner claimed by SchmandtBesserat and Damerow. Instead, these qualities might well indicate fairly elaborate constructs of number. They were laden with intra- and inter-system relations, differentiated materially and perhaps linguistically as well, and fully suited to calculating mentally with numberwords; the use of tokens, impressions, and notations represented a further turn toward mathematical elaboration.

If the ancient object-specific number systems were derived from a method of counting, it might be possible

\footnotetext{
${ }^{143}$ The literacy involved in reading the words in this footnote is a cognitive state that emerges when a society handwrites conventionalized, non-numerical signs at the volume demanded by a bureaucratic state over generations; over time, the material form of writing changes to reflect incremental behavioral-psychological change in its users, distributes this change to new users when they learn to read and write, and gains increasing fidelity to language (Overmann, "Beyond Writing" [2016]: 290-93 and Material Origin [2019], 187-95). Literacy in this sense involves the ability to recognize signs topologically, which over time relaxes their need to depict and allows them to covary; it differs from "this means that" associations between early written forms and semantic ranges, which depend instead on the sign resembling an object (e.g., jar) or conventional form (quartered circle).

${ }^{144}$ Overmann, "Constructing a Concept" (2018): 476 and $\mathrm{Ma}$ terial Origin (2019), 197.
} 


\begin{tabular}{|c|c|c|}
\hline Purpose & Shapes and Sizes & Specifiers \\
\hline$S^{\prime}$ : Certain objects & $D \leftarrow \bullet \leftarrow D$ & - \\
\hline$B$ : Food rations & $0 \leftarrow 8 \leftarrow 8 \leftarrow D \leftarrow \bullet \leftarrow D$ & \\
\hline$B^{*}$ : Certain rations & $8 \leftarrow 8 \leftarrow D \leftarrow \bullet \leftarrow D$ & $\equiv$ or \|\|$\|$ \\
\hline$\breve{S}^{\prime}:$ Grain (malt) & - $\leftarrow D$ & $\chi$ \\
\hline$\check{S}^{\prime \prime}$ : Grain (emmer) & $0 \leftarrow D \leftarrow D \leftarrow 0 \leftarrow \cdot \leftarrow D$ & $==$ \\
\hline$\check{S}^{*}$ : Grain (groats) & $D \leftarrow 0 \leftarrow \bullet \leftarrow D$ & $\because$ \\
\hline Multipliers & 8 & \\
\hline
\end{tabular}

Figure 7-Proto-cuneiform Shapes, Sizes, and Possible Classifiers. Several of the specialized number systems can be reduced to a vocabulary of basic shapes and sizes by removing modifiers. Once removed, the modifiers can be categorized as performing specifying or multiplying functions. These functions evoke the similar features in Polynesian number-words and suggest that the marks may have represented aspects of spoken language, in addition to serving as conventions differentiating signs in visual language. Specifying marks were moved to the rightmost column, while multipliers were removed to the bottom row.

to reconstruct that method, and gain new insight into token-based accounting as currently understood through archaeological means. Admittedly, the endeavor will be challenging. Reconstructing the Polynesian counting method involved evidence that is largely unavailable for Mesopotamian numbers, ${ }^{145}$ since counting behaviors leave little if any archaeological trace, depictions have not been found, and descriptions and lexicons were not possible before the emergence of writing. Although Sumerian number-words currently provide clues to little except finger-counting, ${ }^{146}$ a possible starting point might be to investigate the possibility that object-specific counting was linguistically differentiated in a manner similar to that found in central and peripheral Polynesia. If certain of the specified systems (see Fig. 6) are reduced to their basic shapes and sizes (see Fig. 7), the removed components might be said to specify and multiply, evoking the two functions of numeral classifiers and object-specified counting in Polynesian languages. That is, in addition to serving as conventions differentiating signs in visual language, these marks may have represented aspects of spoken language that might provide insight into the method of counting.

However, the sound values of Sumerian numberwords were not recorded for several centuries or more after writing emerged: "Our knowledge of the Sume-

\footnotetext{
${ }^{145}$ Overmann, "Curious Idea" (2020): 69-73.

146 Diakonoff, “Some Reflections” (1983): 92-93.
}

rian series of number words is derived from lexical lists written down more than 1200 years after the archaic texts. Only the number words from one to ten are attested by two earlier sources, for which the time interval is only a few hundred years." ${ }^{147}$ That is, we do not have phonetic insight into any Sumerian lexical numbers until the early third millennium $\mathrm{BC}$ and as filtered through Akkadian hands, ${ }^{148}$ and then only for the small numbers (one through ten), which the Polynesian case suggests are less likely to have been morphologically differentiated for object-specified counting. Phonetic insight into large Sumerian lexical numbers, which are more likely to be morphologically differentiated, is not available until more than a thousand years after writing emerged. In the central and peripheral portions of Polynesia, over a similar span of time and without encountering other languages to any significant extent, numeral classifiers had largely disappeared and object-specified counting had developed. ${ }^{149}$ This suggests that by the time writing recorded the sound values of Sumerian number-words, little trace of linguistically differentiated counting might have remained, especially for larger values, potentially leaving the proto-cuneiform markings (see Fig. 7) as their only indication.

\footnotetext{
147 Damerow, "Individual Development" (1988): 144.

${ }^{148}$ Civil, "Studies on Early Dynastic Lexicography" (1982): 3-6; Edzard, "Sumerisch 1 bis 10 in Ebla" (1980).

${ }^{149}$ Bender and Beller, "Numeral Classifiers" (2006): 393.
} 


\section{Concluding Remarks}

The notion that "a non-literate culture cannot be expected to advance mathematics beyond the stage of numeral words and counting" 150 requires nuance. Societies without writing in any form are not literate, as a matter of definition. ${ }^{151}$ Notations, numerical or otherwise, were unknown in Polynesia prior to European contact, and traditional Polynesian numeracy was a matter of general and object-specific number-words, elaborate counting behaviors, and material forms like tallies and the commodities sorted as they were counted. Yet Polynesian numbers were relationally complex, and their manipulation involved a degree of mental agility difficult to match once calculation depends on material forms. This numerical elaboration is not surprising, since these societies were complex ${ }^{152}$ and used numbers extensively. ${ }^{153}$

The Mesopotamian societies which used tokens, numerical impressions, and proto-cuneiform notations to count and calculate were also not literate, in the strictest sense of the term. Tokens and impressions were not handwritten and thus could not occasion the neurological reorganization needed for literacy; impressions were numerical and thus lacked the range of language needed to produce literacy; and the non-numerical component of proto-cuneiform had not yet accumulated sufficient behavioral-psychological change to become a system of literacy, though it was on its way to developing as such. ${ }^{154}$ But all these technologies-

150 Tee, "Mathematics in the Pacific Basin" (1988): 401.

${ }^{151}$ Numerical notations need not be written, as they can consist of non-written material forms, like beads on an abacus or notches on a tally. When they are written but unaccompanied by writing for non-numerical language, numerical notations cannot give rise to literacy, as they are only a subset of the language's vocabulary, lack the ambiguity that motivates the inclusion of techniques like phonography to specify the word intended, are semantically sufficient without sound values, and can be rearranged indefinitely without becoming ill-formed or suggesting syntactic and grammatical features of language like word order (Overmann, "Beyond Writing" [2016]: 295).

152 The complexity of Polynesian societies has been claimed to have "approached the formative levels of the old Fertile Crescent civilizations" (Sahlins, "Poor Man, Rich Man" [1961]: 194). This may be an underestimation, given their complex social organization, political stratification, and technology; the latter is convincingly attested by the distances involved in regional colonization and interisland travel, and the navigation and sailing skills required.

${ }^{153}$ Bender and Beller, "Numeral Classifiers" (2006) and "Counting in Tongan" (2007); also see Overmann, "Polynesian Bibliography" (2020).

154 Overmann, "Beyond Writing” (2016): 293-96. notations, impressions, tokens, and the tallies and fingers that preceded them all-were material forms of number, capable of allowing numerical information to be represented and manipulated. The combination of tokens and notations in particular enabled relational knowledge to increase to an unprecedented extent, and calculations became so complex that they first strained and then exceeded the limits of human memory and attention, necessarily involving and becoming dependent on material forms for their representation and manipulation.

There is a curious tension in the idea that mathematics - the seeming height of abstractness in numbersgained increased calculational complexity through the use of material forms like tokens and notations and the relational knowledge they conjointly enabled, while losing some of the mental agility implicit to extracting and exchanging factors in number-words. This trajectory reaches perhaps its fullest extent in the Western mathematical tradition, where numbers have become a single sequence characterized by the potential for an extremely dense intra-system relatedness; even simple algorithms can involve interim steps at volumes imposing substantial if not unsupportable demands on cognitive resources; and calculation relies on material forms like notations and calculators to reduce mental effort to a manageable level. Of the two case studies considered here, Polynesian numbers might seem the more abstract, given that the absence of notational forms like tokens implies a greater dependence on in-the-head manipulation. On the other hand, thinking of number concepts in terms of abstractness and concreteness misunderstands their nature, which is always a mix of neural activity, material forms instantiating numerical information, and behaviors interfacing the two, independent of the degree of elaboration achieved in any particular number system. What the comparison shows is how the incorporation of different material forms alters the respective contribution of these components.

The comparison also challenges the idea that "number" is a monolithic construct, one identical to what contemporary Western numbers are today. ${ }^{155}$ This view of numbers is partly an effect of what numbers are, concepts realized and elaborated through the interaction of shared psychological processes, physiological characteristics, behaviors, and systematized material forms, processes that produce highly similar outcomes

155 Rotman, Mathematics as Sign (2000), 40. 
cross-culturally. ${ }^{156}$ It is partly an effect of the asymmetry inherent in understanding less elaborated numbers from the perspective of highly elaborated ones, a subset effect, where the reverse implies absent concepts and properties. ${ }^{157}$ It is also partly an effect of language, which does not readily discriminate between the highly relational entity that is three in the Western numerical tradition; the discrete and ordinally sequenced three in Papua New Guinean body-counting ${ }^{158}$; and the fuzzy concept about three in an emerging number system. ${ }^{159}$ To this list must now be added the three that has more relations than those of ordinal accumulation but fewer than the potentially infinite Western set, a category that would include both of the case studies considered here.

The comparison of traditional Polynesian and Mesopotamian numbers challenges the idea of a monolithic construct, first by revealing significant differences in characteristics like relatedness, and second by showing how these are ultimately traceable to the material forms used. The Polynesian number systems had extensive intra-system relations; these were facilitated by the counting method, which both accumulated and grouped in a manner analogous to an abacus. The counting method also provided a basis for inter-system relations, in equating quantities like twenty singles, ten pairs, and five fours realized by differences in the unit of counting. Yet a device made of commodities is not easy to manipulate in the way needed for calculations more complex than the simplest arithmetic, and it is certainly not persistent in the way needed to display or record even a single result.

As for archaic Mesopotamian numbers, if the intraand inter-system relations between tokens used for counting began as a method of counting and associated number-words similar to those of Polynesian, they would ultimately become much more extensively elaborated. This was particularly true of the general number system (analogous to the positive portion of the Western number line, absent its anchoring zero) in the form of relations like multiplication and reciprocals. Where rearranging tokens had entailed losing their previous arrangement, recording them with notations allowed comparisons of whole-part relations in a way

\footnotetext{
156 Overmann, "Constructing a Concept" (2018), 464-65 and Material Origin (2019), 43-106.

${ }^{157}$ Ibid., 207-209

${ }^{158}$ Saxe, Cultural Development (2012).

159 Rooryck, et al., "Mundurucu Number Words" (2017).
}

that had not been feasible with tokens alone. ${ }^{160}$ Tables of such relations acted as scale models, enabling not just the collection of data at volume but their concurrent appreciation. ${ }^{161}$ Visual apprehension of the relations and the patterns they formed yielded knowledge and new conceptualizations of numbers. ${ }^{162}$ Coupled with the material abstraction of numbers away from the goods they enumerated, notations and tables and their creation and memorization as part of scribal training caused numbers to be increasingly conceived in terms of their relations, elements of a system in which the relations were critical to what numbers were, in the same way notes are to music and sounds to language. ${ }^{163}$

Ultimately, the ability to understand materially represented numbers whose elaborational status is poorly understood, like those represented by tokens and impressions in the mid-to-late fourth millennium BC, may require that they be compared to highly elaborated, unwritten number systems like those of Polynesia. The key to understanding the latter, in turn, may be examining not just their numerical structure and linguistic expression, but their material substrate as well.

\section{Works Cited}

Aikhenvald, Alexandra Y., Classifiers: A Typology of Noun Categorization Devices (Oxford, 2000).

Amiet, Pierre, "Il y a 5000 Ans Les Élamites Inventaient l'Écriture," Archéologia 12 (1966): 16-23.

—. Mémoires de la délégation archéologique en Iran, Tome XLIII, Missione de Susiane, 2 vols., Mémoires de la délégation en Perse (MDP) 43 (Paris, 1972).

Andrews, Lorrin, A Vocabulary of Words in the Hawaiian Language (Lahainaluna, 1836).

Balbi, Adriano, "Observations sur la Classification des Langues Océaniennes," in Atlas Ethnographique du Globe, ou Classification des Peuples Anciens et Modernes d'Aprés Leur Langue, Vol. 1 (Paris, 1826), 230-78.

Beller, Sieghard and Andrea Bender, "The Cognitive Advantages of Counting Specifically: An Analysis of Polynesian Number Systems," Proceedings of the Annual Meeting of the Cognitive Science Society 27 (2005): 214-19.

\footnotetext{
${ }^{160}$ For example, if ten tokens ("whole") were evenly split into two piles, two groups of five each ("parts") would exist, but the original group of ten would not. However, if "ten" were recorded notationally, the whole would be preserved to permit its comparison to the parts instantiated by tokens.

${ }^{161}$ Lévi-Strauss, La Pensée Sauvage (1962), 34-36.

${ }^{162}$ Giaquinto, Visual Thinking (2007); Nelsen, Proofs without Words (1993).

163 Jowett, "Philebus" (1892), 582-84.
} 
Bender, Andrea and Sieghard Beller, "Counting in Tongan: The Traditional Number Systems and Their Cognitive Implications," Journal of Cognition and Culture 7 (2007): 213-39.

_ Adapting Tools for Numerical Cognition to Cultural Needs," Proceedings of the Annual Meeting of the Cognitive Science Society 30 (2008): 905-10.

_ , "Fanciful' or Genuine? Bases and High Numerals in Polynesian Number Systems," Journal of the Polynesian Society 115 (2006): 7-46.

_ , "Mangarevan Invention of Binary Steps for Easier Calculation," PNAS 111 (2014): 1322-27.

_ nesian and Micronesian Languages: Common Roots and Cultural Adaptations," Oceanic Linguistics 45 (2006): $380-403$.

, "Numeral Classifiers in Specific Counting Systems: Cultural Context, Linguistic Principles, and Cognitive Implications," in Proceedings of the Annual Meeting of the Cognitive Science Society 29 (2007): 821-26.

_ "Numeration Systems as Cultural Tools for Numerical Cognition," in Mathematical Cognition and Learning, Vol. 4, ed. D. B. Berch, D. C. Geary, and K. M. Koepke (Amsterdam, 2018), 297-319.

_ , "The Power of 2: How an Apparently Irregular Numeration System Facilitates Mental Arithmetic," Cognitive Science 41 (2017): 158-87.

Best, Elsdon, "Māori Numeration: Some Account of the Single, Binary, and Semi-Vigesimal Systems of Numeration Formerly Employed by the Māori," Transactions and Proceedings of the New Zealand Institute 39 (1906): 150-80.

Black, J. A., et al., The Electronic Text Corpus of Sumerian Literature (http://etcsl.orinst.ox.ac.uk/), Oxford 1998-2006.

Blažek, Václav, "Afroasiatic Migrations: Linguistic Evidence" (Brno, n.d.). http://www.phil.muni.cz/jazyk/files/AAmi grationsCORR.pdf.

- Numerals: Comparative Etymological Analyses and Their Implications (Brno, 1999).

Bowern, Claire, and Jason Zentz, "Diversity in the $\mathrm{Nu}^{-}$ meral Systems of Australian Languages," Anthropological Linguistics 54 (2012): 133-60.

Broman, Vivian L., Jarmo Figurines (Cambridge, 1958).

Buzacott, Aaron, Te Akataka Reo Rarotonga, or, Rarotongan and English Grammar (Rarotonga, 1854).

Chambers, Geoffrey K., "Genetics and the Origins of the Polynesians" (ELS Wiley Online Library, 2013). https:// doi.org/10.1002/9780470015902.a0020808.pub2.

Chamisso, Adelbert von, "Du Grand Océan, de ses Îles et de ses Côtes," in Annales Maritimes et Coloniales, Année 1825 - II.e Partie - Tome 2, ed. L.-M. Bajot (Paris, 1825), 1-41.

, Über Die Hawaiische Sprache (Leipzig, 1837).

Chrisomalis, Stephen, "The Cognitive and Cultural Foundations of Numbers," in The Oxford Handbook of the
History of Mathematics, ed. E. Robson and J. Stedall (Oxford, 2009), 495-517.

, "Evaluating Ancient Numeracy: Social versus Developmental Perspectives on Ancient Mesopotamian Numeration," paper presented at the annual meeting of the Jean Piaget Society (Vancouver, 2005).

- Numerical Notation: A Comparative History (Cambridge, 2010).

Churchward, Clerk Maxwell, Tongan Grammar (Nuku'alofa, 1985).

Civil, Miguel, "Studies on Early Dynastic Lexicography I," OrAnt 21 (1982): 1-26.

Clark, Ephraim Weston, "Hawaiian Method of Computation," The Hawaiian Spectator 2 (1839): 91-94.

Clark, Ross, "Proto-Polynesian Numerals," in Selected Papers from the Eighth International Conference on Austronesian Linguistics, ed. E. Zeitoun and P. J.-K. Li (Taipei, 1999), 195-204.

Coltheart, Max, "The Neuronal Recycling Hypothesis for Reading and the Question of Reading Universals," Mind \& Language 29 (2014): 255-69.

Comrie, Bernard, "Numeral Bases," in World Atlas of Language Structures Online, ed. M. S. Dryer and M. Haspelmath (Leipzig, 2013). http://wals.info/chapter/131.

Conant, Levi Leonard, The Number Concept: Its Origin and Development (New York, 1896).

Cook, James, A Voyage towards the South Pole and Round the World, Performed in His Majesty's Ships, the Resolution and Adventure, in the Years 1772, 1773, 1774 and 1775, Vol. 2, Book III (London, 1777).

Crook, William Pascoe, An Account of the Marquesas Islands, 1797-1799 (Papeete, 2007).

Dahl, Jacob L., "Comment on 'Numerosity Structures the Expression of Quantity in Lexical Numbers and Grammatical Number," Current Anthropology 56 (2015): 647-48.

Damerow, Peter, Abstraction and Representation: Essays on the Cultural Evolution of Thinking, Boston Studies in the Philosophy of Science 175 (Dordrecht, 2010).

_ , "Individual Development and Cultural Evolution of Arithmetical Thinking," in Ontogeny, Phylogeny, and Historical Development: The Tel Aviv Annual Workshop in Human Development, ed. S. Strauss, Human Development 2 (Norwood, 1988), 125-52.

- "The Material Culture of Calculation: A Theoretical Framework for a Historical Epistemology for the Concept of Number," in Mathematisation and Demathematisation: Social, Philosophical and Educational Ramifications, ed. U. Gellert and E. Jablonka (Rotterdam, 2007), 19-56.

- "Number as a Second-Order Concept," Science in Context 9 (1996): 139-49.

- "The Origins of Writing and Arithmetic," in The Globalization of Knowledge in History, ed. J. Renn (Berlin, 2012), 153-73.

_ , "Prehistory and Cognitive Development," in Invited Lecture at the Twenty-Fifth Annual Symposium of the Jean 
Piaget Society Berkeley, June I - June 3, 1995, ed. M. Killen (Berlin, 1996), 1-37.

Damerow, Peter and Hans-Peter Meinzer, "Computertomografische Untersuchung Ungeöffneter Archaischer Tonkugeln Aus Uruk, W 20987, 9, W 20987, 11 und W 20987, 12," Baghdader Mitteilungen 26 (1995): 7-33.

Damerow, Peter and Robert K. Englund, Die zablzeichensysteme der archaischen texte aus Uruk, Archaische Texte aus Uruk (ATU) 2 (Berlin, 1987).

Damerow, Peter, Robert K. Englund, and Hans J. Nissen, "Die Ersten Zahldarstellungen und die Entwicklung des Zahlbegriffs," Spektrum der Wissenschaft 3 (1988): 46-55.

Davletshin, Albert, "Numerals and Phonetic Complements in the 'Kohau Rongorongo' Script of Easter Island," Journal of the Polynesian Society 121 (2012): 243-74.

Dehaene, Stanislas, "The Neural Basis of the WeberFechner Law: A Logarithmic Mental Number Line," Trends in Cognitive Sciences 7 (2003): 145-47.

Dehaene, Stanislas and Laurent Cohen, "Cultural Recycling of Cortical Maps," Neuron 56 (2007): 384-98.

Dehaene, Stanislas, et al., "Illiterate to Literate: Behavioural and Cerebral Changes Induced by Reading Acquisition," Nature Reviews: Neuroscience 16 (2015): 234-44

Diakonoff, Igor M., "Some Reflections on Numerals in Sumerian: Towards a History of Mathematical Speculation," JAOS 103 (1983): 84-92.

Döhler, Christian, A Grammar of Komnzo, Studies in Diversity Linguistics 22 (Berlin, 2018).

Dreyfus, Tommy, "Advanced Mathematical Thinking Processes," in Advanced Mathematical Thinking, ed. D. Tall (New York, 1991), 25-41.

Durrad, W. J., "A Tikopia Vocabulary," Journal of the Polynesian Society 22 (1913): 86-95.

Edzard, Dietz O., "Sumerisch 1 bis 10 in Ebla," Studi Eblaiti III (1980): 121-27.

Ehret, Christopher, Reconstructing Proto-Afroasiatic (ProtoAfrasian): Vowels, Tone, Consonants, and Vocabulary (Berkeley, 1995).

Ellis, William, Narrative of a Tour through Hawaii, or Owbyhee (London, 1826).

Englund, Robert K., "An Examination of the 'Textual' Witnesses to the Late Uruk World Systems," in Special Issue of Oriental Studies: A Collection of Papers on Ancient Civilizations of Western Asia, Asia Minor and North Africa, ed. Y. Gong and Y. Chen (Beijing, 2006), 1-38.

—, Archaic Administrative Texts from Uruk: The Early Campaigns. Archaische Texte aus Uruk (ATU) 5 (Berlin, 1994).

__ , "Review: Denise Schmandt-Besserat, How Writing Came About," Written Language and Literacy 1 (1998): 257-61.

_ - "The State of Decipherment of Proto-Elamite," in The First Writing: Script Invention as History and Process, ed. S. D. Houston (Cambridge, 2004), 100-49.
— "Texts from the Late Uruk Period," in Mesopotamien: Späturuk-Zeit und Frühdynastische Zeit, ed. J. Bauer, R. K. Englund, and M. Krebernik (Freiburg, 1998), 15-233.

Epps, Patience, "Growing a Numeral System: The Historical Development of Numerals in an Amazonian Language Family," Diachronica 23 (2006): 259-88.

Epps, Patience, et al., "On Numeral Complexity in HunterGatherer Languages," Linguistic Typology 16 (2012): 41109

Evans, Nicholas, "Two Pus One Makes Thirteen: Senary Numerals in the Morehead-Maro Region," Linguistic Typology 13 (2009): 321-35.

Ferrari, Pier L., "Abstraction in Mathematics," Philosophical Transactions of the Royal Society of London B 358 (2003): 1225-30.

Fischer, Steven R., Rongorongo: The Easter Island Script (Oxford, 1997).

Forster, John Feinold, "Chap. VI. Remarks on the Human Species in the South-Sea Isles," in Observations Made during a Voyage Round the World, on Physical Geography, Natural History, and Ethic Philosophy (London, 1778), 212-84.

Frege, Gottlob, The Foundations of Arithmetic: A LogicalMathematical Investigation into the Concept of Number, 2nd rev. (New York, 1953).

Friberg, Jöran, "Preliterate Counting and Accounting in the Middle East: A Constructively Critical Review of Schmandt-Besserat's Before Writing," Orientalistische Literaturzeitung 89 (1994): 477-89.

Fuentes, Jordi, Diccionario y Gramática de la Lengua de la Isla de Pascua (Santiago, 1960).

Giaquinto, Marcus, Visual Thinking in Mathematics: An Epistemological Study (Oxford, 2007).

González de Haedo, Don Felipe, The Voyage of Captain Don Felipe Gonzalez in the Ship of the Line San Lorenzo, with the Frigate Santa Rosalia in Company, to Easter Island in 1770-1771 (Cambridge, 2007).

Gray, Eddie M. and David O. Tall, "Duality, Ambiguity, and Flexibility: A 'Proceptual' View of Simple Arithmetic," Journal for Research in Mathematics Education 25 (1994): 116-40.

Guérin, Valérie, "The Oceanic Subgroup of the Austronesian Language Family," in The Cambridge Handbook of Linguistic Typology, ed. A. Y. Aikhenvald and R. M. W. Dixon (Cambridge, 2017), 911-41.

Hale, Horatio, United States Exploring Expedition. During the Years 1838, 1839, 1840, 1841, 1842, Vol. IV (Philadelphia, 1846).

Handy, Edward Smith Craighill, The Native Culture in the Marquesas (Honolulu, 1923).

Harrison, Sheldon P. and Frederick H. Jackson, "Higher Numerals in Several Micronesian Languages," in Studies in 
Micronesian Linguistics, ed. B. W. Bender, Pacific Linguistics C-80 (Canberra, 1984), 61-79.

Henkelman, Wouter F. M. and Margaretha L. Folmer, "Your Tally Is Full! On Wooden Credit Records in and after the Achaemenid Empire," in Silver, Money, and Credit: A Tribute to Robartus J. Van der Spek on the Occasion of His 65th Birthday, ed. K. Kleber and R. Pirngruber (Leiden, 2016), 133-239.

Hiroa, Te Rangi, Ethnology of Mangareva (Honolulu, 1938).

Howorth, Henry H., "The Later Rulers of Shirpurla or Lagash," The English Historical Review XVII/LXV (1902): 1-14, 209-34.

Høyrup, Jens, In Measure, Number, and Weight: Studies in Mathematics and Culture (Albany, 1994).

- Lengths, Widths, Surfaces: A Portrait of Old Babylonian Algebra and Its Kin (New York, 2002).

Huehnergard, John, "Proto-Semitic," in The Semitic Languages, 2nd ed., ed. J. Huehnergard and N. Pat-El (New York, 2019), 49-79.

Hurles, Matthew E., et al., "Untangling Oceanic Settlement: The Edge of the Knowable," Trends in Ecology of Evolution 18 (2003): 531-40.

Hutchins, Edwin, "Material Anchors for Conceptual Blends," Journal of Pragmatics 37 (2005): 1555-77.

Hyman, Malcolm D., "Of Glyphs and Glottography," Language \& Communication 26 (2006): 231-49.

Janeau, Vincent-Ferrier, Essai de Grammaire de la Langue des Iles Gambier ou Mangaréva (Braine-le-Comte, 1908).

Jaussen, Tepano, Grammaire et Dictionnaire de la Langue Maorie, Dialecte Tahitien (Braine-le-Comte, 1861).

Jowett, Benjamin, "Philebus," in The Dialogues of Plato, 3rd ed., Vol. 4 (New York, 1892).

Kanepuu, J. H., "Ka Helu Hawaii [Hawaiian Numbers]," Ke Au Okoa 2 (1867): 3.

Kirch, Patrick V., The Evolution of the Polynesian Chiefdoms (Cambridge, 1984).

Labillardière, Jacques Julien Houton de, "Appendix: Vocabulaire de la Langue des Iles des Amis," in Relation du Voyage à la Recherche de La Pérouse, Fait par Ordre de l'Assemblee Constituante, Pendant les Années 1791, 1792, et Pendant la lère et la 2de Année de la République Françoise, Vol. II (Paris, 1799), 41-50.

Lach, Donald F., Asia in the Making of Europe, Vol. I, Book 2 (Chicago, 1994).

Lazaridis, Iosif, et al., "Genomic Insights into the Origin of Farming in the Ancient Near East," Nature 536 (2016): 419-24.

Lemaître, Yves, "Les Systèmes de Numération en Polynésie Orientale," Journal de la Société des Océanistes 41 (1985): 3-13.

Lesson, René-Primevère and Prosper Garnot, Voyage $A u$ tour du Monde, Exécuté par Ordre du Roi, sur la Corvette de Sa Majesté, La Coquille, Pendant les Années 1822-1825: Zoologie, Vol. 1 (Paris, 1826).

Lévi-Strauss, Claude, La Pensée Sauvage (Paris, 1962).

Lévy-Bruhl, Lucien, L'âme Primitive (Paris, 1927).

- Les Fonctions Mentales dans les Sociétés Inférieures (Paris: 1912).

Lieberman, Stephan J., "Of Clay Pebbles, Hollow Clay Balls, and Writing: A Sumerian View," American Journal of Archaeology 84 (1980): 339-58.

Lipínski, Edward, Semitic Languages: Outline of a Comparative Grammar, 2nd ed. (Leuven, 2001).

Lipson, Mark, et al., "Population Turnover in Remote Oceania Shortly after Initial Settlement," Current Biology 28 (2018): 1157-65.

Lynch, John, Malcolm Ross, and Terry Crowley, The Oceanic Languages (Richmond, 2002).

Malafouris, Lambros, "Grasping the Concept of Number: How Did the Sapient Mind Move beyond Approximation?" In The Archaeology of Measurement: Comprehending Heaven, Earth and Time in Ancient Societies, ed. C. Renfrew and I. Morley (Cambridge, 2010), 35-42.

- How Things Shape the Mind: A Theory of Material Engagement (Cambridge, 2013).

Martin, John, An Account of the Natives of the Tonga Islands, in the South Pacific Ocean, Vol. II (London, 1818).

Métraux, Alfred, "Numerals from Easter Island," Man 36 (1936): 190-91.

Michalowski, Piotr, "Review: Tokenism," American Anthropologist, New Series 95 (1993): 996-99.

Miller, Douglas B. and Mark R. Shipp, An Akkadian Handbook: Helps, Paradigms, Glossary, Logograms, and Sign List, 2nd ed. (Winona Lake, IN, 2014).

Moore, Andrew and Michael Tangye, "Stone and Other Artifacts," in Village on the Euphrates: From Foraging to Farming at Abu Hureyra, ed. A. Moore, et al. (Oxford, 2000), 165-86.

Nelsen, Roger B., Proofs without Words: Exercises in Visual Thinking, Vol. 1 (Washington, DC, 1993).

Nissen, Hans J., "The Archaic Texts from Uruk," World Archaeology 17 (1986): 317-34.

Nissen, Hans J., Peter Damerow, and Robert K. Englund, Archaic Bookkeeping: Early Writing and Techniques of Economic Administration in the Ancient Near East (Chicago, 1993).

Oates, Joan, "Early Writing in Sumer: A Review, Cambridge Archaeological Journal 3 (1993): 149-53.

Oppenheim, A. Leo, "On an Operational Device in Mesopotamian Bureaucracy," JNES 18 (1959): 121-28.

Overmann, Karenleigh A., "Beyond Writing: The Development of Literacy in the Ancient Near East," Cambridge Archaeological Journal 26 (2016): 285-303.

- "Constructing a Concept of Number," Journal of Numerical Cognition 4 (2018): 464-93. 
" "Counting by 'Elevens' and Why Nine and Two Make Twenty: The Material Roots of Polynesian Numbers," Journal of Mathematics and Culture 15 (2021): 1-32.

_ - "The Curious Idea That Māori Once Counted by Elevens, and the Insights It Still Holds for Cross-Cultural Numerical Research," Journal of the Polynesian Society 129 (2020): 59-84

, "Material Scaffolds in Numbers and Time," Cambridge Archaeological Journal 23 (2013): 19-39.

- The Material Origin of Numbers: Insights from the Archaeology of the Ancient Near East, Gorgias Studies in the Ancient Near East 14 (Piscataway, 2019).

, "Polynesian Bibliography: Analytical Data for EU Project 785793" (Open source dataset, 2020). https:// doi.org/10.13140/RG.2.2.31010.04809/1.

- "The Role of Materiality in Numerical Cognition," Quaternary International 405 (2016): 42-51.

_ , 'Updating the 'Abstract-Concrete' Distinction in Ancient Near Eastern Numbers," Cuneiform Digital Library Journal 1 (2018): 1-22.

Peirce, Charles Sanders, "Prolegomena to an Apology for Pragmaticism," The Monist 16 (1906): 492-546.

Piaget, Jean, The Child's Conception of Number (Abingdon, 1952).

__ "Logique Génétique et Sociologie," Revue Philosophique de la France et de l'Étranger 105 (1928): 167-205.

Piazza, Manuela, "Neurocognitive Start-up Tools for Symbolic Number Representations," Trends in Cognitive Sciences 14 (2010): 542-51.

Powell, Marvin A. Jr., "Notes on Akkadian Numbers and Number Syntax," Journal of Semitic Studies 24 (1979): 13-8.

, "The Origin of the Sexagesimal System: The Interaction of Language and Writing," Visible Language 6 (1972): 5-18.

_ , "Sumerian Area Measures and the Alleged Decimal Substratum," ZA 62 (1972): 165-221.

Proust, Christine, "Du Calcul Flottant en Mésopotamie," La Gazette des Mathématiciens 138 (2013): 23-48.

Rabone, Stephen, A Vocabulary of the Tonga Language (Vava'u, 1845).

Ricklefs, Merle C., A History of Modern Indonesia: C. 1300 to the Present (Bloomington, 1981).

Rieth, Timothy and Ethan E. Cochrane, "The Chronology of Colonization in Remote Oceania," in The Oxford Handbook of Prehistoric Oceania, ed. E. E. Cochrane and T. L. Hunt (Oxford, 2018), 133-61.

Robson, Eleanor, Mathematics in Ancient Iraq: A Social History (Princeton, 2008).

_ , "Mesopotamian Mathematics," in The Mathematics of Egypt, Mesopotamia, China, India, and Islam: A Sourcebook, ed. V. Katz (Princeton, 2007), 57-186.

Rooryck, Johan, et al., "Mundurucu Number Words as a Window on Short-Term Memory" (London, 2017). https://halshs.archives-ouvertes.fr/halshs-01497577.
Rotman, Brian, Mathematics as Sign: Writing, Imagining, Counting (Stanford, 2000)

Roussel, Hippolyte, Vocabulaire de la Langue de l'île-dePâques ou Rapanni, Le Muséon Études Philologiques, Historiques, et Religieuses, Nouvelle Série IX (Louvain, 1908).

Russell, Bertrand, Introduction to Mathematical Philosophy, 2nd ed. (London, 1920).

, "The Theory of Logical Types," in Essays in Analysis, ed. D. Lackey (New York, 1910), 215-52.

Sahlins, Marshall D., "Poor Man, Rich Man, Big Man, Chief: Political Types in Melanesia and Polynesia," Comparative Studies in Society and History 5 (1963): 285-303.

Saxe, Geoffrey B., Cultural Development of Mathematical Ideas (Cambridge, 2012).

Schlaudt, Oliver, "Type and Token in the Prehistoric Origins of Numbers," Cambridge Archaeological Journal 30 (2020): 629-46.

Schlimm, Dirk. "Numbers through Numerals: The Constitutive Role of External Representations," in Naturalizing Logico-Mathematical Knowledge: Approaches from Psychology and Cognitive Science, ed. S. Bangu (New York, 2018), 195-217.

Schmandt-Besserat, Denise, "An Archaic Recording System and the Origin of Writing," Syro-Mesopotamian Studies 1 (1977): 1-28.

, Before Writing. Vol. 1, From Counting to Cuneiform;

Vol. 2, A Catalog of Near Eastern Tokens (Austin, 1992).

, "The Earliest Precursor of Writing," Scientific American 238 (1978): 50-59.

, "The Emergence of Recording," American Anthropologist, New Series 84 (1982): 871-78.

, "From Tokens to Tablets: A Re-evaluation of the Socalled 'Numerical Tablets', Visible Language 15 (1981): 321-44.

- How Writing Came About (Austin, 1992).

-, "Prehistoric Administrative Technologies and the Ancient Near Eastern Redistribution Economy: The Case of Greater Susiana," in The Elamite World, ed. J. Álvarez-Mon, G. P. Basello, and Y. Wicks (New York, 2018), 363-82.

, "The Token System of the Ancient Near East: Its Role in Counting, Writing, the Economy and Cognition," in The Archaeology of Measurement: Comprehending Heaven, Earth and Time in Ancient Societies, ed. C. Renfrew and I. Morley (Cambridge, 2010), 27-34.

- "The Use of Clay before Pottery in the Zagros," Expedition 16 (1974): 11-17.

Seidenberg, Abraham, "The Sixty System of Sumer," Archive for History of Exact Sciences 2 (1965): 436-40.

Sfard, Anna and Liora Linchevski, "The Gains and the Pitfalls of Reification? The Case of Algebra," Educational Studies in Mathematics 26 (1994): 191-228.

Shendge, Malati J., "The Use of Seals and the Invention of Writing," Journal of the Economic and Social History of the Orient 26 (1983): 113-36. 
Sizer, Walter S., "Base and Subbase in a Number System," The Humanistic Mathematics Network Journal 27 (2004): $1-5$.

Soames, Scott, The Dawn of Analysis, Philosophical Analysis in the Twentieth Century 1 (Princeton, 2003).

Stimson, J. Frank, A Dictionary of Some Tuamotuan Dialects of the Polynesian Language (Salem, 1964).

Suggs, Robert C., Archaeology of Nuku Hiva, Marquesas Islands, French Polynesia. Anthropological Papers of the American Museum of Natural History 49 Part 1 (New York, 1961).

Tavernier, Jan, "Elamite," in A Companion to Ancient Near Eastern Languages, ed. R. Hasselbach-Andee (Hoboken, 2020), 163-84.

Tee, Garry J., "Mathematics in the Pacific Basin," British Journal for the History of Science 21 (1988): 401-17.

Thomson, James B., Practical Arithmetic, Uniting the Inductive with the Synthetic Mode of Instruction (New Haven, 1846).

Thureau-Dangin, François, "Le Nouveau Cône d'Urukagina," Orientalistiche Litterature-Zeitung 10 (1900): 38384 .

"Sketch of a History of the Sexagesimal System," Osiris 7 (1939): 95-141.
Tregear, Edward, A Dictionary of Mangareva (or Gambier Islands) (Wellington, 1899).

Valério, Miguel and Silvia Ferrara, "Numeracy at the Dawn of Writing: Mesopotamia and Beyond," Historia Mathematica (2021): 1-19.

Veldhuis, Niek, "Levels of Literacy," in The Oxford Handbook of Cuneiform Culture, ed. K. Radner and E. Robson (Oxford, 2011), 68-89.

Williams, Francis E., Papuans of the Trans-Fly (Oxford, 1936).

Woods, Christopher, "The Abacus in Mesopotamia: Considerations from a Comparative Perspective," in The First Ninety Years: A Sumerian Celebration in Honor of Miguel Civil, ed. L. Feliu, F. Karahashi, and G. Rubio, Studies in Ancient Near Eastern Records 12 (Boston, 2017), 41678 .

"Bilingualism, Scribal Learning, and the Death of Sumerian," in Margins of Writing, Origins of Cultures, ed. S. L. Sanders, Oriental Institute Seminars 2 (Chicago, 2006), 91-120.

Zimansky, Paul, "Review of Denise Schmandt-Besserat's Before Writing, Volumes I and II," Journal of Field Archaeology 20 (1993): 513-17. 